\title{
FOCAL ADHESIONS:
}

Transmembrane Junctions Between the Extracellular Matrix and the Cytoskeleton

Keith Burridge, Karl Fath, Thomas Kelly, Glen Nuckolls, and Christopher Turner

Department of Cell Biology and Anatomy, CB \# 7090, 108 Swing Building, University of North Carolina at Chapel Hill, Chapel Hill, North Carolina 27599

\section{CONTENTS}

INTRODUCTION.

MORPHOLOGY AND OBSERVATION OF FOCAL ADHESIONS …........................................... 488

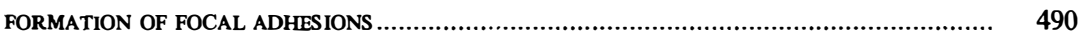

DYNAMICS OF FOCAL ADHESION COMPONENTS ............................................................... 491

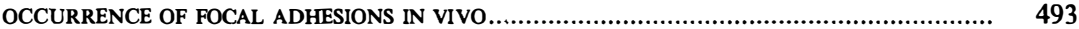

COMPOSITION OF FOCAL ADHESIONS ...................................................................... 494

Extracellular Matrix Components .................................................................... 494

Membrane Components .................................................................................... 496

Cytoplasmic Components................................................................................. 500

Organization of Focal Adhesions ....................................................................... 504

FACTORS AFFECTING FOCAL ADHESIONS ....................................................................... 505

Hormones and Growth Factors ....................................................................... 505

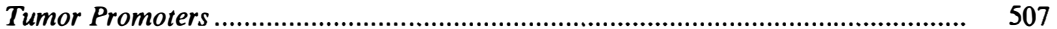

Viral Transformation.................................................................................. 508

Abnormal "Rosette" Adhesions ("Podosomes") in RSV-transformed Cells............. 510

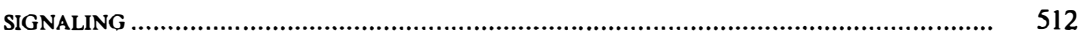

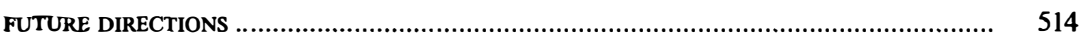

\section{INTRODUCTION}

Many cells grown in tissue culture adhere tightly to the underlying substrate through discrete regions of the plasma membrane, referred to as 
adhesion plaques, focal contacts, or focal adhesions. In these regions where the surface of the cell comes closest to the substrate, the plasma membrane is specialized at its cytoplasmic face for anchoring stress fibers, the large bundles of microfilaments that are prominent in many cultured cells. In this review we discuss the composition and organization of focal adhesions. Many of their characteristics indicate that they are structurally and functionally equivalent to the adhesions made by many cells to the extracellular matrix (ECM) in vivo. We also consider the regulatory proteins that have been identified in focal adhesions since these regions are interesting not only as models for studying the links between the extracellular matrix and the cytoskeleton, but also as sites of transmembrane communication between the extracellular environment and the cytoplasm. Many features of focal adhesions, some of which are not considered here, have been reviewed previously (Burridge 1986; Woods \& Couchman 1988).

\section{MORPHOLOGY AND OBSERVATION OF FOCAL ADHESIONS}

Focal adhesions were first identified in electron microscope studies of cultured fibroblasts (Abercrombie et al 1971). It was noted that some regions of the "ventral" cell surface were much closer to the substrate than others. These regions exhibited an increased electron density, and microfilaments were associated with local dense "plaques" on the cytoplasmic face of the membrane. While electron microscopy continues to be used to study focal adhesions, particularly in conjunction with immunological markers for specific components, its potential to reveal many of the ultrastructural details has been frustrated by the high electron density of these regions, which makes difficult (or impossible) the visualization of the ends of individual actin filaments and of their interactions with the cell membrane.

Interference reflection microscopy (IRM) is a light microscope technique introduced into biological study by Curtis (1964) in order to examine the relationship of the ventral surface of cells to the substrate. Izzard \& Lochner (1976) used IRM to classify the ventral surface of cultured cells into three types of regions according to the degree of proximity of the plasma membrane to the substrate. The closest regions, which appeared black by IRM, had a separation of $10-15 \mathrm{~nm}$ from the substrate and were referred to as "focal contacts." Gray images, corresponding to a separation of about $30 \mathrm{~nm}$, were called "close contacts." Finally, some regions appeared faint gray or white, which indicated a separation of $100 \mathrm{~nm}$ or more from the substrate. Cells can adhere to the substrate by both focal and close contacts. Whereas close contacts often extend over broad areas, 
focal contacts are confined, typically $2-10 \mu \mathrm{m}$ long and $0.25-0.5 \mu \mathrm{m}$ wide. The theoretical basis of IRM and some of its potential pitfalls have been discussed elsewhere (Curtis 1964; Izzard \& Lochner 1976, 1980; BereiterHahn et al 1979; Gingell 1981).

Using both electron microscopy and IRM on the same cells confirmed that the adhesion plaques seen by electron microscopy are the same as focal contacts revealed by IRM (Abercrombie \& Dunn 1975; Heath \& Dunn 1978). Henceforth we use the hybrid term "focal adhesion" for these structures because it carries the functional connotation of adhesion as well as indicating that they are associated with discrete regions of the plasma membrane. The use of IRM in combination with immunofluorescence microscopy was valuable in confirming the presence of specific proteins such as vinculin in focal adhesions (Geiger 1979). Subsequently, immunofluorescence microscopy with antibodies against vinculin has become a routine method for visualizing these adhesive specializations. This is particularly useful in studying newly formed focal adhesions, which are difficult to detect by IRM (Geiger et al 1984a,b; Bershadsky et al 1985). However, caution is required because vinculin is also detected in other cellular locations (see below) and can be mobilized selectively from focal adhesions in response to certain agents (Herman \& Pledger 1985). Visualization of focal adhesions by both IRM and immunofluorescence with antibodies against talin is illustrated in Figure 1.

"antibody-exclusion" technique has also been used to visualize focal adhesions (Neyfakh et al 1983). When cells are grown in serum, antibodies
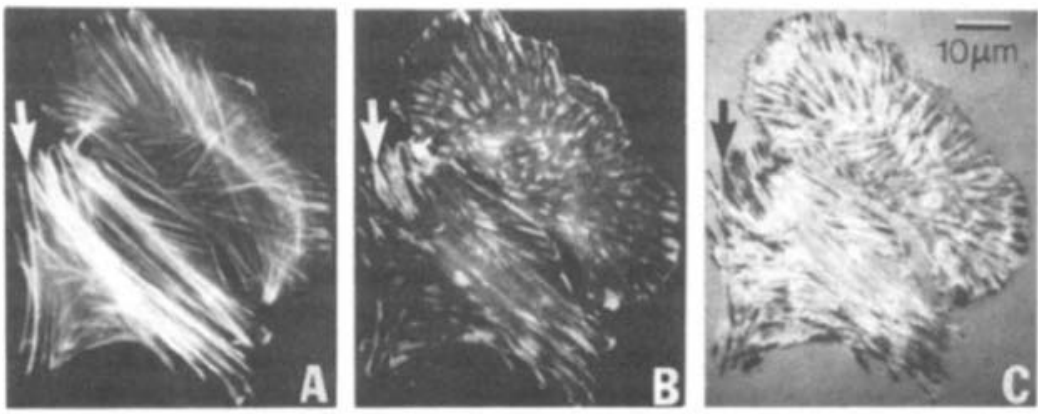

Figure 1 The organization of stress fibers and focal adhesions in two chicken embryo fibroblasts. $(A)$ The distribution of actin revealed with rhodamine phalloidin; $(B)$ the distribution of talin in the same cells revealed by anti-talin followed by a fluorescein-labeled second antibody; $(C)$ the interference reflection image of the same cells. The stress fibers stain prominently for actin and terminate at focal adhesions that stain for talin and appear black by IRM (arrows). 
the focal adhesions, which appear dark on a fluorescent background. If the cells are detergent extracted prior to staining, the vitronectin beneath the adhesions is also stained.

Several techniques have been developed for isolating focal adhesions based on the observation that these regions are the most adherent parts of cultured cells. In most of these methods, a stream of buffer has been used to detach the bulk of the cell while leaving behind the focal adhesions attached to the dish or coverslip (Badley et al 1978; Cathcart \& Culp 1979; Avnur \& Geiger 1981a; Avnur et al 1983; Neyfakh \& Svitkina 1983; Ball et al 1986; Nicol \& Nermut 1987). These preparations have been useful in studying the binding of purified proteins to focal adhesions (Avnur et al 1983; Ball et al 1986), but for biochemical analysis they yield only very small amounts of material. In general, focal adhesion proteins that have been characterized in detail have been isolated from smooth muscle such as chicken gizzard (e.g. Geiger 1979; Feramisco \& Burridge 1980; Burridge \& Connell 1983a; Molony et al 1987b).

\section{FORMATION OF FOCAL ADHESIONS}

Many cells, including fibroblasts, epithelial cells, endothelial cells, and platelets, form focal adhesions when plated onto appropriate substrates. When focal adhesions were first discovered and were noted to be associated with stress fibers, they were considered important in cell migration (Abercrombie et al 1971). They are most prominent, however, in stationary cells and absent from some highly migratory cells (Couchman \& Rees 1979; Kolega et al 1982). An inverse correlation was similarly found between stress fibers and movement (Herman et al 1981; Couchman et al 1982). While studying the migration of cells from a tissue explant, it was noted that initially the cells were highly motile; they revealed close contacts rather than focal adhesions and lacked stress fibers. With time, the cells developed focal adhesions and stress fibers. This change in morphology correlated with a decrease in migration (Couchman \& Rees 1979; Couchman et al 1982).

Although prominent in relatively stationary cells, focal adhesions usually form within or just behind the ruffling leading edge of motile cells (Izzard \& Lochner 1980). Persistent ruffling has been noted above focal adhesions, as if the adhesion is itself a stimulus for this activity (Geiger et al 1984b; Small \& Rinnerthaler 1985). There is often a correlation between ruffling and the later formation of a focal adhesion at the same site (Rinnerthaler et al 1988).

The formation of focal adhesions is preceded by a structural precursor 
consisting of a microspike or bundle of actin filaments oriented radially within the leading edge of a cell (Izzard \& Lochner 1980; DePasquale \& Izzard 1987; Izzard 1988; Rinnerthaler et al 1988). Observation of these precursors by light microscopy has brought new insight into the events leading to focal adhesion formation. The precursors can be divided into two portions: a proximal part that becomes stationary and forms the plaque on the cytoplasmic face of the focal adhesion membrane, and a distal part, which continues to advance with the leading edge (DePasquale \& Izzard 1987). Talin, but not vinculin, has been detected at the leading edge and is concentrated at the tips of the distal portion of the precursors (Izzard 1988) where microfilaments terminate in an electron dense patch of material associated with the plasma membrane (Small 1981). As the precursor separates physically into two parts, talin remains with the leading edge and a second population of talin accumulates in the developing focal adhesion with approximately the same time course as vinculin accumulation at this site (Izzard 1988).

After their initial formation, some focal adhesions disassemble while others enlarge and nucleate associated stress fibers. The maturation of focal adhesions is disrupted in some transformed cells; such cells contain at their margins many small adhesion sites that fail to enlarge and acquire attached stress fibers (Bershadsky et al 1985). While studying the maturation of focal adhesions, it was noted that the more stable focal adhesions were of ten associated with the ends of microtubules (Geiger et al 1984b; Small \& Rinnerthaler 1985; Rinnerthaler et al 1988). In addition, disruption of microtubules by treatment with nocodazole increased the number of small (immature) focal adhesions at the periphery (Small \& Rinnerthaler 1985). These results suggest that association with microtubules may increase focal adhesion stability and promote nucleation of stress fibers (Geiger et al 1984b; Small \& Rinnerthaler 1985; Rinnerthaler et al 1988). The recent finding that some intermediate filaments also terminate at focal adhesions (Green \& Goldman 1986; Bershadsky et al 1987) has led to a similar suggestion: The association of intermediate filaments with focal adhesions may stabilize these structures (Bershadsky et al 1987). Focal adhesions may also be stabilized at their extracellular face by the deposition of additional components. For example, it was found that a heparan sulfate proteoglycan was absent from many focal adhesions 6 hours after plating cells, but was prominent in these structures after 24 hours in culture (Singer et al 1987a).

\section{DYNAMICS OF FOCAL ADHESION COMPONENTS}

The dynamics of focal adhesion components has been studied by fluorescence recovery after photobleaching (Geiger et al 1982, 1984a; Kreis et 
al 1982). In the plane of the membrane of a focal adhesion, there is little resistance to the diffusion of lipid components, but the lateral diffusion of membrane proteins is retarded (Geiger et al 1982). The same approach has been used to study the dynamics of proteins such as vinculin, $\alpha$ actinin, and actin after the microinjection of fluorescent derivatives of these proteins into live cells and their incorporation into the cytoskeleton (Kreis et al 1982; Geiger et al 1984a). Outside the regions of focal adhesions, 60 $80 \%$ of the injected protein is free to diff use, but within focal adhesion regions, the mobility of these proteins is greatly reduced. Within focal adhesions, a very slow recovery of fluorescence was observed after spot photobleaching. The half time of recovery $(2-4 \mathrm{~min})$ suggests slow exchange of proteins between the focal adhesion and the surrounding cytoplasmic pool of proteins (Geiger et al 1984a). A similar result was obtained by Stickel \& Wang (1987). However, these investigators found that the abnormal adhesions (podosomes) formed in Rous sarcoma virus (RSV)-transformed cells (discussed below) showed a very rapid exchange of components, with a half time of recovery on the order of a few seconds.

Although protein exchange occurs within focal adhesions, these structures are usually stable for long periods once they have matured from initially small adhesion sites. Nevertheless, net movement of entire focal adhesions has been described. Without the loss of their associated stress fibers, two focal adhesions were observed to translocate about $4 \mu \mathrm{m}$ relative to each other over a period of about $90 \mathrm{~min}$ (Sanger et al 1987). How this movement occurred has not been determined, but it indicates that these adhesions may be more dynamic than previously considered.

Focal adhesions are clearly important for anchoring stress fibers to the plasma membrane, but they probably also regulate the assembly and disassembly of the attached actin filaments. In support of actin polymerization being nucleated at these sites, fluorescently derivatized actin microinjected into cells concentrates at newly formed focal adhesions (Kreis et al 1982; Wang 1984). Some proteins found in focal adhesions may regulate the assembly and disassembly of actin filaments. This process may be quite complex, enabling tension to be transmitted to the membrane while simultaneously allowing these actin filaments to elongate or shorten. Studying the assembly of stress fibers in cells microinjected with fluorescent actin, Wang observed that the stress fibers appeared to elongate from the focal adhesions, either in the front or rear of the cell (Wang 1984). In general, the focal adhesions remained stationary relative to the substrate as the cells moved forward although the orientation of stress fibers sometimes changed. Disassembly of stress fibers was observed from both ends (Wang 1984). 
Focal adhesions are of ten considered to be artifacts of tissue culture because they are prominent in many cultured cells but less obvious in most cells within whole organisms. The focal adhesions of cultured cells are unusual primarily because of their planar configuration and the size of the associated stress fibers. The planar configuration is clearly imposed by the growth of cultured cells on flat, rigid substrates. The size and prominence of stress fibers in cultured cells has been discussed previously (Burridge 1981, 1986; Byers et al 1984) and appears to be due in part to the strong adhesions made with the rigid substrate (the culture dish or coverslip) and to the consequent isometric tension generated by the associated microfilaments. In contrast, fibroblasts grown in collagen gels lack discernible stress fibers and focal adhesions (Tomasek et al 1982).

There are, however, several cell types in the body that develop adhesions structurally similar, if not identical, to the focal adhesions seen in tissue culture. One of the best examples is the dense plaque of smooth muscle cells. Like the focal adhesion, the plaque is a junction between the ECM on the outside of the cell and the contractile microfilament system on the inside. Although in cross sections they appear as discrete plaques applied to the membrane, in longitudinal sections these structures may extend the length of the muscle cell (Small 1985). Dense plaques contain essentially the same repertoire of proteins as focal adhesions, including vinculin (Geiger et al 1980, 1981), talin (Geiger et al 1985, Drenckhahn et al 1988), and integrin (S. C. Mueller, W.-T. Chen, personal communication). The presence of $\alpha$-actinin has also been reported in the dense plaques of smooth muscle cells (Schollmeyer et al 1976), where it was noted to be farther from the plasma membrane than vinculin (Geiger et al 1981). A more recent study found little or no $\alpha$-actinin in the dense plaques (Small 1985). The reason for this apparent discrepancy needs to be explored.

The myotendinous junction of skeletal muscle also shares structural and functional characteristics with focal adhesions; it is a specialized region of the plasma membrane that anchors actin filaments and transmits their tension across the membrane to the ECM. In this case, the ECM forms the tendon. It has been calculated that during maximum isometric tension, the stress placed on the myotendinous junction is $\sim 2 \times 10^{4} \mathrm{~N}$ (Newtons) $/ \mathrm{m}^{2}$, and that this correlates closely with the shear stress generated at the sites of fibroblast adhesion $\left(\sim 10^{4} \mathrm{~N} / \mathrm{m}^{2}\right)$ (Tidball et al 1986). Again, several prominent focal adhesion proteins have been identified in myotendinous junctions, including vinculin (Shear \& Bloch 1985), talin (Tidball et al 1986), and integrin (Boszycko et al 1988). The presence of $\alpha$-actinin in myotendinous junctions and in smooth muscle dense plaques (Tidball 1987) has been questioned. 
Several focal adhesion proteins have been localized to another region in skeletal muscle fibers, the postsynaptic region of neuromuscular junctions (Bloch \& Hall 1983; Sealock et al 1986). This is not a region where tension is expected to be transmitted across the membrane, which suggests that these proteins have a different function in neuromuscular junctions, perhaps organizing acetylcholine receptor clusters. Recent work on muscles from Xenopus laevis, however, has indicated that not all neuromuscular junctions contain talin (M. W. Rochlin et al, manuscript submitted). The reasons for this variability are not clear.

Superficially, a focal adhesion resembles the zonula adherens junction between adjacent epithelial cells. Geiger and coworkers showed that these cell-cell junctions have a somewhat different composition than focal adhesions and classified adherens junctions into two types on the basis of their constituent proteins (Geiger et al 1985): cell-cell junctions that lack talin but contain a 135-kDa cell adhesion molecule (Volk \& Geiger 1984) and cell-ECM junctions that lack this cell adhesion molecule but contain talin. Both types of junction contain vinculin, which indicates that the presence of this protein at the membrane does not depend on talin (see below). Epithelial cells have been shown to contain low levels of talin, confined to the basal surface where these cells adhere to the underlying basement membrane (Drenckhahn et al 1988).

Many proteins found in fibroblast focal adhesions are present in large amounts in blood platelets (Rosenberg et al 1981; Collier \& Wang 1982; Koteliansky et al 1984; O'Halloran et al 1985; Rosenfeld et al 1985). Platelets form focal adhesions when plated on appropriate substrates (Zobel \& Woods 1983; Alexandrova \& Vasiliev 1984), and adhesion to the ECM is essential to their function in vivo. For example, platelet adhesion to the subendothelial ECM, exposed by blood vessel injury, triggers platelet activation. In turn, this stimulates increased adhesiveness to other ECM proteins and promotes platelet aggregation. Platelet adhesion is a complex subject beyond the scope of this review; however, many of the details of this system are relevant to the formation and organization of focal adhesions in fibroblasts and other cells.

\section{COMPOSITION OF FOCAL ADHESIONS}

\section{Extracellular Matrix Components}

The composition of the substrate is critical in determining the adhesive behavior of cells. Fibroblasts adhere well to surfaces coated with various ECM proteins, such as fibronectin (FN) or vitronectin (VN); they subsequently spread on these substrates and develop focal adhesions. In contrast, normal fibroblasts adhere poorly and fail to develop focal adhesions 
when plated on naked glass in the absence of serum or on glass coated with nonspecific proteins, such as bovine serum albumin (BSA). Some spreading may occur with time, but this depends on the synthesis and secretion of FN, which adsorbs onto the adjacent substrate (Grinnell \& Feld 1979). Despite the enhancing effect of FN on focal adhesion formation (Couchman et al 1982; Laterra et al 1983; Woods et al 1986), the actual relationship of FN to these adhesive structures has been controversial. FN was reported to be present in established focal adhesions by some investigators (Grinnell 1980; Singer \& Paradiso 1981), but others found that it was notably absent (Chen \& Singer 1980; Birchmeier et al 1980; Badley et al 1980). In addition, Avnur \& Geiger (1981b) found that cells plated onto substrates coated with fluorescent FN specifically cleared it from focal adhesion regions both by centripetal movement on the surface toward the nucleus and by endocytosis. An explanation for these apparently conflicting results was suggested by Grinnell (1986), who found that the adsorption of $\mathrm{FN}$ to glass was weakened significantly by the presence of other proteins. As a result of this situation, cells grown in the presence of serum were able to clear any FN from focal adhesions, whereas cells grown in the absence of serum (or low serum) were unable to remove FN from the substrate, and it was then detected within focal adhesions.

Much emphasis has been placed upon the role played by FN in the formation of focal adhesions. By comparison, rather little attention has been given to $\mathrm{VN}$ even though its properties suggest that it may have a critical role in the formation of focal adhesions when cells are cultured in the presence of serum. VN (also known as serum spreading factor) was first identified as a serum protein that promotes adhesion of cells to glass or plastic substrates (Holmes 1967; Barnes et al 1983; Hayman et al 1983). The majority of the adhesion-promoting activity in serum is accounted for by VN (Hayman et al 1985). It adsorbs tenaciously to glass so that cells plated onto coverslips in the presence of serum are essentially plated onto a VN substrate. Unlike FN, VN is not cleared from focal adhesions when cells are grown in serum although to detect it beneath these adhesions requires that the cells are permeabilized and extracted prior to fixation, presumably because it is inaccessible to antibodies beneath these adhesions (Neyfakh et al 1983; Baetscher et al 1986). Since serum is usually present, VN is likely to be a major extracellular component of focal adhesions in most culture conditions.

FN and VN are structurally quite different, but along with several other ECM proteins, they share two features that appear to be important for the formation of focal adhesions. The first is a cell-binding domain containing the amino acid sequence Arg-Gly-Asp (RGD), which has been identified in many ECM proteins that interact with cells (Ruoslahti \& 
Pierschbacher 1987). Secondly, both proteins contain a heparin-binding domain. Several studies have investigated the role of the RGD sequence in focal adhesion formation. Fibroblasts have been plated on cell-binding fragments of FN or on short synthetic peptides containing the RGD sequence, which have been linked covalently to the substrate. On these substrates some cells adhere well, spread, and develop focal adhesions (Singer et al 1987a). Other cell types adhere to the cell-binding fragment of FN, but fail to develop focal adhesions (Beyth \& Culp 1984; Izzard et al 1986; Woods et al 1986) or only form small abnormal adhesions (Streeter \& Rees 1987). This second group of cells could be induced to form focal adhesions and associated stress fibers if the heparin-binding domain of FN was also adsorbed to the substrate or even if it was added in solution (Woods et al 1986). The need for the heparin-binding domain of FN suggests that a heparan sulfate proteoglycan (HSPG) is involved in formation of focal adhesions although the HSPG-binding domain alone is also insufficient to induce focal adhesions (Laterra et al 1983). HSPGs have been found on the surface of several cell types (Kjellen et al 1981; Rapraeger \& Bernfield 1983; Woods et al 1985) and have also been detected in focal adhesions (Woods et al 1984; Singer et al 1987b) and in the material remaining on the substrate when cells are detached with calcium chelators (Laterra et al 1980; Lark \& Culp 1984). Further support for a role of proteoglycans in formation of focal adhesions comes from a cell line that is defective in proteoglycan synthesis and is unable to develop focal adhesions when plated on intact FN (LeBaron et al 1988).

The experiments with ECM proteins and their fragments define the substrate requirements for focal adhesions: The ECM protein must contain an RGD sequence and usually a heparin-binding domain as well.

\section{Membrane Components}

Several integral membrane components have been identified in focal adhesions (Table 1). Most interest has been generated by the integrins for the obvious reason that the members of this family of proteins are receptors for ECM components. Because the integrins have been reviewed in detail (Buck \& Horwitz 1987a; Hynes 1987; Ruoslahti \& Pierschbacher 1987), they are considered here only briefly. Two approaches led to the identification of the FN receptor, a member of the integrin family. In one approach, both polyclonal and monoclonal antibodies were generated, which perturbed cell adhesion (Neff et al 1982; Greve \& Gottlieb 1982; Tarone et al 1982; Brown \& Juliano 1985). These antibodies have been used extensively to identify and characterize the cell surface proteins involved in adhesion (Chapman 1984; Horwitz et al 1985; Knudsen et al 1985; Hasegawa et al 1985; Giancotti et al 1985, 1986). In the avian system, the 
Table 1 Structural proteins in focal adhesions

Extracellular face

Vitronectin (65 and $80 \mathrm{kDa}$ )

Fibronectin $(\sim 250 \mathrm{kDa})^{\mathrm{a}}$

Heparan sulfate proteoglycan
Transmembrane

Integrin $(\sim 140 \mathrm{kDa})$

30B6 antigen (130 kDa)

HSV D glycoprotein

Cytoplasmic face

\author{
Actin (42 kDa) \\ $\alpha$-actinin (100 kDa) \\ Fimbrin (68 kDa) \\ Vinculin $(115 \mathrm{kDa})^{\mathrm{b}}$ \\ Talin (225 kDa) \\ Tensin (200 and $150 \mathrm{kDa}$ ) \\ $200 \mathrm{kDa}$ \\ $82 \mathrm{kDa}$ \\ FC-1 (60 and > $300 \mathrm{kDa}$ ) \\ 80 and $75 \mathrm{kDa}$ or $54 \mathrm{kDa}^{\mathrm{c}}$
}

\footnotetext{
a The presence of fibronectin in focal adhesions appears to depend on whether the cells are grown in the presence of serum or not (Grinnell 1986).

${ }^{b}$ Vinculin was originally considered to have a molecular weight of 130,000 (Geiger 1979; Feramisco \& Burridge 1980), but it migrates on SDS polyacrylamide gels just ahead of $\boldsymbol{\beta}$-galactosidase which has a molecular weight of 116,000 .

${ }^{c}$ Antigens in focal adhesions recognized by human autoantisera show different molecular weights with different cell types (Senecal et al 1987).
}

isolated receptor complex was shown to bind to $\mathrm{FN}, \mathrm{VN}$, and laminin (Horwitz et al 1985; Akiyama et al 1986; Buck \& Horwitz 1987b). A different approach with mammalian cells used affinity chromatography of cell extracts on immobilized FN fragments, VN, or synthetic peptides followed by elution with cell-binding domain peptides containing the RGD sequence (Pytela et al 1985a,b; Cheresh 1987; Cheresh \& Spiro 1987). This approach resulted in the isolation of distinct receptors for FN and VN (Pytela et al 1985a,b); in spite of binding to the common RGD sequence, these receptors displayed a narrow ligand specificity, binding either to FN or VN, but not to both. In contrast, other integrins interact with multiple ECM proteins. This is true for the avian integrin mentioned above, as well as for the mammalian integrin found on platelets, glycoproteins IIb/IIIa, which bind to FN, fibrinogen, and von Willebrand's factor (Bennett \& Vilaire 1979; Ruggeri et al 1982; Ginsberg et al 1983; Parise \& Phillips 1986; Plow et al 1985; Gardner \& Hynes 1985; Pytela et al 1986). Platelets, however, also contain a second form of integrin, glycoprotein Ic/IIa, with a narrower specificity, that binds FN but not these other ECM proteins (Giancotti et al 1987; Pischel et al 1988; Piotrowicz et al 1988).

The integrins constitute a large family of receptors that have been detected across the animal kingdom, from nematodes and arthropods to frogs, birds, and mammals (Bogaert et al 1987; Leptin et al 1987; DeSimone \& Hynes 1988; Marcantonio \& Hynes 1988; Hynes et al 1988). The recep- 
tors are heterodimers, with the $\alpha$-chains often cleaved into two subunits that are linked by a disulfide bond. Several $\alpha$ and $\beta$ chain genes have been cloned and sequenced. Each chain contains a putative transmembrane domain, a short C-terminal cytoplasmic domain, and a large extracellular domain. The predicted existence of a cytoplasmic sequence has been confirmed immunologically for the $\beta$ chain (Mueller et al 1988; Marcantonio $\&$ Hynes 1988). In general, the $\beta$ chains show more homology between different receptors and across species than the $\alpha$ chains; moreover, the cytoplasmic and transmembrane domains of $\beta$ chains reveal considerable sequence homology (Hynes 1987; Hynes et al 1988).

The distribution of integrin was explored in avian cells using the monoclonal antibodies (mabs) CSAT and JG22E, both of which perturb cellsubstrate adhesion. Migratory cells were labeled diffusely by these antibodies, but more stationary cells revealed labeling of focal adhesions and, not surprisingly, of a fibrillar pattern on the cell surface coincident with bundles of FN (Chen et al 1985b; Damsky et al 1985). The precise distribution of integrin detected in focal adhesions, however, was unexpected: The staining was concentrated at the periphery of these structures in a pattern like the eye of a needle. This uneven distribution appears to be the result of using these particular mabs since subsequent work with other antibodies indicated that integrin is distributed more uniformly throughout the focal adhesion (Giancotti et al 1986; Kelly et al 1987). The peripheral staining of focal adhesions obtained with CSAT or JG22E probably arises because these antibodies interact with epitopes that are more accessible at the periphery of these structures.

It is worth noting that integrin in avian cells is concentrated even within those focal adhesions lacking FN. This suggests that the integrin binds to another ECM component, most probably VN. In mammalian cells, where distinct receptors exist for $\mathrm{FN}$ and $\mathrm{VN}$, it is possible to ask which receptor is present in focal adhesions. Using antibodies specific for the $\alpha$ chains of each receptor, Singer and coworkers (1988) found that only the FN receptor occurred in the focal adhesions of fibroblasts plated on FN, but when cells were plated in the presense of serum, both receptors were initially present in focal adhesions. However, as the cells began to assemble FNcontaining ECM fibers, the FN receptor was redistributed away from the focal adhesions to locations underlying these ECM bundles. With time, only the VN receptor was detected in the focal adhesions. In another study, however, only the VN receptor was detected in the focal adhesions formed by endothelial cells plated on serum-coated coverslips (K. Fath, K. Burridge, unpublished observations). If these endothelial cells were plated on FN substrates, initially the FN receptor was expressed in focal adhesions, but in the presence of serum the FN receptor was progressively 
replaced by the VN receptor (K. Fath, K. Burridge, unpublished observations). In most mature focal adhesions, the VN receptor is the predominant integrin isoform present. Since the cytoplasmic domains of the various integrins are so similar, we suspect that the specific integrin aggregated in the focal adhesion is relatively unimportant and that any integrin clustered in the adhesion induces similar cytoplasmic organization.

The existence of a transmembrane link between the ECM and the cytoskeleton has been recognized for some time. This has been based on morphological evidence (Singer 1979; Chen \& Singer 1982), on functional studies in which $\mathrm{FN}$ added to transformed cells temporarily restored stress fibers (Yamada et al 1976; Ali et al 1977; Willingham et al 1977), and on the observation that disruption of the actin cytoskeleton resulted in a loss of FN from the cell surface (Ali \& Hynes 1977; Kurkinen et al 1978). The integrins are an obvious candidate for this linkage. Now we must understand how the cytoplasmic domains of the integrin $\alpha$ and $\beta$ chains associate with the cytoskeleton. The potential interactions of detergentsolubilized integrin with various cytoskeletal proteins have been investigated. Binding was detected between integrin and talin, albeit with a low affinity (Horwitz et al 1986). This interaction is inhibited by a synthetic peptide corresponding to a conserved sequence in the integrin $\beta$ chain cytoplasmic domain (Buck \& Horwitz 1987b; P. Tapley et al unpublished observations). While this interaction between integrin and talin suggests one transmembrane link between the ECM and the cytoskeleton, the low affinity of the binding leads us to speculate that other proteins may also be involved. Of course, the observed low affinity could reflect inappropriate assay conditions or the absence of additional factors. Some support for the latter possibility has come from experiments examining the distribution of integrin and talin in avian lymphocytes. When integrin on the lymphocyte surface was aggregated and capped with antibodies, talin codistributed with integrin only if the cells were treated with tumor promoters (Burn et al 1988). These agents activate protein kinase $C$, which suggests that phosphorylation of one of these components may increase the affinity of their interaction. However, these effects should be contrasted with the disruption of focal adhesions in other cells by tumor promoters (see below).

Other integral membrane proteins have also been identified in focal adhesions such as the Herpes simplex virus D glycoprotein (Norrild et al 1983 ) and the 30B6 antigen (Rogalski \& Singer 1985). The 30B6 antigen shares many properties with integrin. Analysis of this antigen has been performed primarily in chicken gizzard, where it has a molecular weight of 130,000 and it is associated with a $175-\mathrm{kDa}$ polypeptide (Rogalski \& Singer 1985; Rogalski 1987). Although molecular weights distinguish this complex from the avian integrins originally isolated from fibroblasts or 
eviscerated embryos, an integrin isolated from chicken smooth muscle has polypeptides of molecular weights similar to those identified by the 30B6 mab (Kelly et al 1987). Consequently, we surmise that the $30 \mathrm{~B} 6 \mathrm{mab}$ is binding to an integrin isoform (Kelly et al 1987).

\section{Cytoplasmic Components}

Vinculin and talin are two prominent components of focal adhesions (Geiger 1979; Burridge \& Feramisco 1980; Burridge \& Connell 1983a). Within fibroblasts they also codistribute beneath bundles of FN (Burridge \& Feramisco 1980; Singer \& Paradiso 1981; Burridge \& Connell 1983a,b), but talin appears more abundant in fibroblast ruffling membranes (Burridge \& Connell 1983a; Izzard 1988). In other cell types, however, there are some distinct regions where the two proteins do not codistribute. As mentioned above, the zonula adherens junctions of epithelia stain prominently for vinculin but talin is not detected, which distinguishes cellECM junctions from cell-cell junctions (Geiger et al 1985). Geiger and colleagues also noted that in the embryonic development of chicken gizzard, talin is detected within dense plaques prior to vinculin (Volberg et al 1986). Another situation where talin is concentrated without vinculin has been observed by Kupfer and colleagues who studied lymphocyte interactions. When cytotoxic $\mathrm{T}$ lymphocytes adhere to their target cells, talin but not vinculin is concentrated in the $\mathrm{T}$ cell at the site of adhesion (Kupfer et al 1986). Similarly, the adhesion of helper T cells to antigenpresenting B cells results in the concentration of talin at the site of adhesion in the $\mathrm{T}$ cell (Kupfer et al 1987). These are clearly cell-cell interactions, and therefore one might predict that vinculin rather than talin would be localized at these sites of adhesion. Unlike epithelial zonula adherens junctions, however, these adhesive interactions involve members of the integrin family (Kishimoto et al 1987), which, as discussed above, are prominent in focal adhesions and have been shown to bind talin (Horwitz et al 1986).

In spite of different distributions in some cell types, vinculin and talin purified from smooth muscle bind to each other with high affinity (Burridge \& Mangeat 1984). Their independent behavior in some cells could be accounted for by certain isoforms of the two proteins that lack the appropriate binding site for the other protein. Isof orms of vinculin have been detected (Geiger 1982; Gimona et al 1987), and recent work on the cloning and sequencing of the vinculin gene support this possibility. Vinculin has been sequenced (Price et al 1987), and the potential talin-binding site has been localized within a 41-amino acid sequence (D. R. Critchley, personal communication). In one cDNA clone of the vinculin gene, this internal sequence was absent (D. R. Critchley, personal communication). It is 
important to determine if this binding site is absent from vinculin purified from cells in which the two proteins display distinct distributions. Nevertheless, direct binding to talin is not required for the localization of vinculin to focal adhesions. Study of the expression of cloned vinculin genes with regions of the molecule deleted has revealed that deletion of the talinbinding site does not affect the localization of this truncated vinculin in focal adhesions (R. Bendori, D. Salomon, B. Geiger, personal communication). Furthermore, vinculin can be added back to focal adhesions of extracted cells (Avnur et al 1983), in which its binding occurs independently of talin (Ball et al 1986).

These results, together with the finding of vinculin at membrane sites where talin is absent, indicate that other vinculin-binding proteins must be important for linking vinculin to the membrane. Several vinculin-binding proteins, besides talin, have been detected using $\left[{ }^{125} \mathrm{I}\right]$ vinculin in Western blots and binding assays (Otto 1983; Wilkins et al 1983; Burridge \& Mangeat 1984; Koteliansky et al 1985; Belkin \& Koteliansky 1987), but most of these proteins have not been characterized. Shortly after vinculin was discovered, evidence was presented for an interaction with actin (Jockusch \& Isenberg 1981; Burridge \& Feramisco 1982; Wilkins \& Lin 1982), but subsequent work revealed that this was due to contaminants in vinculin preparations (Evans et al 1984; Schroer \& Wegner 1985; Wilkins $\&$ Lin 1986); more highly purified vinculin did not bind actin (Evans et al 1984; Rosenfeld et al 1985; Otto 1986). Pursuit of the contaminating, actinbinding activity led to the identification of a set of low molecular weight proteins referred to as $\mathrm{HAl}$ (since these flowed through hydroxylapatite columns) (Wilkins \& Lin 1986; Wilkins et al 1986). Antisera raised against HA1 reacted with much higher molecular weight bands ( 150 and $200 \mathrm{kDa})$ (Wilkins et al 1986) that have been named tensin (Wilkins et al 1987; Risinger et al 1987). It is suspected that some of the HAl proteins are proteolytic fragments of tensin. The relationship of the two tensin bands is not clear. Antisera to tensin and HA1 stain focal adhesions, and tensin binds to vinculin (Wilkins et al 1987). Although originally HAl was thought to cap the ends of actin filaments and therefore to regulate polymerization, it is not clear whether tensin or other proteins present in the contaminant fractions are responsible for this activity (S. Lin, personal communication).

Of the several cytoplasmic proteins in focal adhesions (Table 1), so far only fimbrin and $\alpha$-actinin have been shown to bind actin directly. The only source from which fimbrin has been purified and characterized is microvilli, where it was first discovered (Bretscher \& Weber 1980). It crosslinks actin filaments to form bundles in vitro (Bretscher 1981) and is thought to have a bundling function in vivo since it is localized within the 
actin core of microvilli (Matsudaira \& Burgess 1979). The idea that fimbrin may perform a similar role in focal adhesions remains to be tested. Although, by comparison $\alpha$-actinin has been studied in much greater detail and has been cloned and sequenced (Baron et al 1987a,b), its function remains elusive. Purified $\alpha$-actinin crosslinks actin filaments in vitro but with relatively low affinity (Bennett et al 1984; Sato et al 1987), and with nonmuscle $\alpha$-actinin, the binding to actin is inhibited by calcium (Burridge $\&$ Feramisco 1981). When first identified in nonmuscle cells at the end of stress fibers, it was suggested that $\alpha$-actinin attaches actin filaments to the plasma membrane (Lazarides \& Burridge 1975). In part this suggestion was based on the assumption that $\alpha$-actinin anchored thin filaments to the $\mathbf{Z}$ disc in skeletal muscle. However, this function has not been proved. It is interesting that $\alpha$-actinin has been reported to be absent from the myotendinous junctions of skeletal muscle fibers (Tidball 1987) and the dense plaques of smooth muscle cells (Small 1985), both prominent sites for anchorage of actin filaments to the membrane. Nevertheless, the possibility that $\alpha$-actinin has a role in attachment of actin to focal adhesion membranes has been suggested on the basis of its interaction with specific lipids and with vinculin. The binding of certain lipids by $\alpha$-actinin has been noted (Burn et al 1985), but this is difficult to reconcile with the observation that $\alpha$-actinin is farther from the focal adhesion membrane than other proteins such as vinculin (Chen \& Singer 1982). An interaction between vinculin and $\alpha$-actinin was first detected in Western blots or gel overlays using [ $\left.{ }^{125} \mathrm{I}\right]$ vinculin (Otto 1983; Wilkins et al 1983; Burridge \& Mangeat 1984). A low affinity interaction between these two proteins has been detected in solution binding assays (Craig 1985; Wachsstock et al 1987). The interaction between vinculin and $\alpha$-actinin suggests one way actin filaments may be anchored to the membrane (illustrated in Figure 2), but for several reasons (discussed below), we suspect that there may be other, more important modes of attachment. It should be noted that in most cells $\alpha$-actinin and vinculin have very different distributions: $\alpha$-actinin has a periodic distribution along stress fibers and only overlaps with vinculin where the stress fibers terminate at focal adhesions. If the interaction of these two proteins detected in vitro also occurs within the cell, then additional factors must regulate this interaction and confine vinculin to regions such as focal adhesions.

Antisera have been used to reveal several additional proteins in focal adhesions. An antibody was raised against a $200-\mathrm{kDa}$ protein in preparations of cardiac intercalated discs (Maher \& Singer 1983). This antibody stained focal adhesions in fibroblasts and did not cross react with talin, which has a similar molecular weight. By screening nonimmunized rabbit sera, Beckerle (1986) discovered one serum that labeled focal adhesions in 
component, but more recent evidence indicates that the reactive antigens $(60 \mathrm{kDa}$ and $>300 \mathrm{kDa})$ are at the cytoplasmic face of the membrane (W. Birchmeier, personal communication).

Most of the proteins discussed above have been considered in the context of how stress fibers are anchored to the plasma membrane at focal adhesions. As mentioned earlier, however, recent evidence has shown that the other two major filament types found in fibroblasts, microtubules, and the vimentin form of intermediate filaments may also terminate in focal adhesions (Geiger et al 1984b; Small \& Rinnerthaler 1985; Green \& Goldman 1986; Bershadsky et al 1987). Little is known about the proteins involved in these attachments.

\section{Organization of Focal Adhesions}

Based on binding experiments in vitro, a chain of attachment of actin to the membrane is suggested (Figure 2), going sequentially via $\alpha$-actinin, vinculin, and talin to integrin; the latter spans the membrane and binds to ECM components outside the cell. Where possible, the proteins represented in Figure 2 have been drawn to scale, with their morphologies based on electron microscopic images (e.g. Milam 1985; Molony et al 1987b). In general, the location of protein binding sites has not been determined; for example, it is not known which part of the vinculin molecule binds to $\alpha$-actinin, or vice versa.

Several observations lead us to question the significance of this chain of protein interactions with respect to linking actin to the membrane in focal adhesions. Several of the interactions illustrated in Figure 2 are of relatively low affinity. Since tension generated in stress fibers is transmitted across the membrane at these sites, a series of low affinity links to the membrane would seem somewhat surprising. It should be remembered, however, that the interaction of integrin with FN is also of low affinity (Horwitz et al 1985); yet this is certainly physiologically significant, as evidenced by the rounding up of cells treated with antibodies or peptides that disrupt this association. Clustering many of the components into close proximity should effectively overcome their tendency to dissociate and should result in a more stable attachment. In addition, talin dimerizes at high concentrations (Molony et al 1987b), which are expected in focal adhesions. Talin dimers have not been illustrated in Figure 2 because their conformation is unknown, but they are expected to stabilize talin's association with vinculin and integrin as a result of crosslinking these components.

Another observation that is difficult to reconcile with vinculin and talin playing a major role in anchoring actin to the membrane, is the high solubility of these components detected when cells are permeabilized with nonionic detergents. Both proteins dissociate quite rapidly from the focal 
adhesions of permeabilized cells. Since the cytoskeleton is generally defined as a detergent-insoluble matrix, talin and vinculin do not behave as typical cytoskeletal proteins. The apparent solubility of vinculin and talin under these conditions may again reflect the low affinity of their interactions, as well as the large dilution that usually accompanies permeabilization. Nevertheless, in these permeabilized cells, stress fibers still appear to be anchored to the ECM, which suggests that other linking proteins must be important or that only a small fraction of the talin and vinculin is required to maintain these linkages. Vinculin and talin may be involved in one chain of attachment, but additional ways of linking actin to the membrane may function in parallel at focal adhesions. Even in the erythrocyte, considered a simple model of actin association with a plasma membrane, two different attachment systems have been elucidated, one via spectrin and ankyrin to the integral membrane protein band 3 (Branton et al 1981), the other via protein 4.1 to the membrane protein glycophorin A (Anderson \& Marchesi 1985). A more direct mode of attachment at focal adhesions is suggested by the observation that two different forms of integrin with actin tightly bound have been isolated (Painter et al 1985; Molony et al 1987a). Preliminary observations indicate that this association does not involve vinculin, talin, or $\alpha$-actinin (our unpublished observations); further characterization is in progress.

These questions about the role of vinculin and talin raise the possibility that these proteins have some other function in addition to (or instead of) attachment. As discussed elsewhere in this review, focal adhesions serve as sites not only to anchor stress fibers but also to nucleate actin polymerization. One possibility, therefore, is that vinculin and talin may have some role in regulating actin nucleation at focal adhesions. It is obvious that the diagram in Figure 2 represents a very incomplete understanding of focal adhesion organization.

\section{FACTORS AFFECTING FOCAL ADHESIONS}

\section{Hormones and Growth Factors}

Agents that elevate intracellular levels of cyclic AMP (cAMP) can have marked effects on cell morphology, the integrity of stress fibers, and focal adhesions. The same agent, however, can have opposite effects in different cell types. Many virally transformed cells, as well as Chinese hamster ovary cells, respond to elevated cAMP by adhering more tightly to the substrate, flattening, and developing stress fibers and focal adhesions (Pastan \& Willingham 1978; Leader et al 1983). Many other cells in culture respond in the opposite manner when stimulated by these agents. In many of 
these studies focal adhesions have not been examined, but stress fibers disassemble and the cells develop a more arborized or stellate morphology. This behavior has been noted with thyroid cells in response to thyrotropin (Westermark \& Porter 1982), with bone cells in response to parathyroid hormone (Aubin et al 1983), and with ovarian granulosa cells in response to follicle stimulating hormone (FSH), prostaglandin $E_{1}$ and $E_{2}$, and cholera toxin (Lawrence et al 1979). In Balb/c-3T3 cells, stress fibers were lost in response to cholera toxin; this was accompanied by a loss of vinculin staining from the focal adhesions (Herman \& Pledger 1985). All the effects of cAMP are believed to occur through its activation of the cAMP-dependent protein kinase. In a recent study, the catalytic subunit of this enzyme, which is active in the absence of the regulatory subunit, was microinjected into fibroblasts. This resulted in the dissolution of stress fibers (Lamb et al 1988), with a subsequent loss of focal adhesions (J. R. Feramisco, personal communication).

Several mitogenic growth factors also affect focal adhesions in receptive cells. For example, in the human epidermoid carcinoma line A431, epidermal growth factor (EGF) stimulates increased membrane ruffling and disassembly of stress fibers as well as focal adhesions, as judged by staining for $\alpha$-actinin (Schlessinger \& Geiger 1981). Similarly, treatment of quiescent Balb/c-3T3 cells with platelet derived growth factor (PDGF) caused disassembly of stress fibers and a rapid mobilization of vinculin out of focal adhesions (Herman \& Pledger 1985). Surprisingly, some focal adhesion staining with anti-talin remained in response to PDGF, which suggests that the structures were not fully disassembled, but components such as vinculin were selectively released. A similar loss of vinculin from the focal adhesions of cultured smooth muscle cells has also been noted in response to PDGF (Herman et al 1987). On its own, PDGF renders Balb/c-3T3 cells competent to respond to other factors such as EGF, insulin, or whole plasma, which stimulate DNA synthesis (Pledger et al 1977). PDGF is a competence factor for these cells; other competence factors, such as fibroblast growth factor, transf orming growth factor $\beta$, and cholera toxin, also induced vinculin mobilization in these cells (Herman et al 1986). The sequence of events leading to vinculin mobilization was investigated using a number of pharmacological reagents. It was concluded that activation of phospholipase $\mathrm{C}$ followed by elevated intracellular free calcium was important in mobilizing vinculin (Herman et al 1986). The loss of vinculin from focal adhesions was inhibited by specific protease inhibitors, which indicates that proteolysis, either of vinculin or possibly some other protein, was involved. Some of these protease inhibitors are known to affect the type II isoform of the calcium-dependent protease (calpain II), which is concentrated in focal adhesions (Beckerle et al 1987; see below). Both 
vinculin and talin are substrates for this enzyme in vitro and proteolysis of talin has been described in vivo (Fox et al 1985).

\section{Tumor Promoters}

Tumor promoters are compounds that are not carcinogenic themselves but increase the frequency of tumors in animals previously exposed to carcinogens. Tumor promoters activate protein kinase $\mathrm{C}$, the calciumactivated, phospholipid-dependent protein kinase that has been implicated in the mitogenic response of various growth factors, such as EGF and PDGF. The response of cultured cells to tumor promoters is often dramatic; the cells develop many of the characteristics of virally transformed cells. Epithelial cells often display the most pronounced response to tumor promoters, and the effect of these agents on the epithelial cytoskeleton has been investigated by several laboratories. Schliwa and coworkers (1984) found that the potent tumor promoter 1-O-tetradecanoylphorbol-13-acetate (TPA) caused the disassembly of stress fibers in BSC-1 cells. The first signs of disruption of stress fibers could be detected within 2 min of TPA application; this was paralleled by extensive ruffling at the cell margins. The disruption of focal adhesions was confirmed both by IRM and by vinculin immunofluorescence. Accompanying its loss from focal adhesions, vinculin could be detected within the membrane ruffles. The disruption of stress fibers induced by TPA preceded the loss of vinculin from focal adhesions, a sequence opposite to that reported for Balb/c-3T3 cells responding to PDGF (Herman \& Pledger 1985). Different cell types, as well as different agents, probably account for these apparently conflicting results.

A similar disruption of stress fibers was observed in Madin-Darby canine kidney (MDCK) cells in response to TPA (Kellie et al 1985). In this study it was shown that the ratio of filamentous to monomeric actin was unaffected by TPA even though the cells underwent a major reorganization of their microfilament cytoskeleton. The effects of TPA on BSC1 cells have also been studied in live cells microinjected with fluorescent $\alpha$ actinin and vinculin by Meigs \& Wang (1986), who noted that focal adhesions, as judged by IRM and vinculin distribution, persisted longer than stress fibers following TPA treatment. However, they noted that the $\alpha$-actinin in focal adhesions was more labile than that in stress fibers. Together with the observation of the selective mobilization of vinculin in response to PDGF, this striking result implies that the interaction of these proteins can be uncoupled and that they can behave independently.

The disassembly of focal adhesions in response to tumor promoters has led to a search for relevant substrates for protein kinase $\mathrm{C}$ in these regions. Both vinculin and talin have been shown to be substrates for this enzyme 
in vitro (Werth et al 1983; Litchfield \& Ball 1986; Beckerle et al 1985), and elevated phosphorylation of vinculin has been detected in cells treated with TPA (Werth \& Pastan 1984). The effects of these phosphorylations on the interactions of vinculin and talin have not been determined. Whereas TPA results in a disruption of focal adhesions in epithelial cells, in lymphocytes it enhances the association of talin with integrin that has been capped by antibody-induced crosslinking (Burn et al 1988).

\section{Viral Transformation}

There are dramatic differences in morphology and behavior between cells transformed by oncogenic viruses and their normal counterparts. Typically, transformed cells are more rounded and less adherent than normal cells; they have reduced focal adhesions and few, if any, stress fibers. Different viruses induce distinct morphologies in the same cell type, which suggests that some of these changes may be brought about in different ways. Both intra- and extra-cellular factors have been invoked. Most transformed cells show alterations at the cell surface, and it is probable that these changes contribute to a loss of focal adhesions. Almost all transformed cells show a decrease in surface FN (Hynes 1973) due to altered patterns of synthesis and increased degradation of this protein (Olden \& Yamada 1977). The loss of FN from the cell surface would be expected to diminish focal adhesions. Indeed, in somecases addition of FN to transformed cells can temporarily restore a more normal morphology (Yamada et al 1976; Ali et al 1977; Willingham et al 1977), including focal adhesions (Chen et al 1986). It has been known for a long time that FN is particularly sensitive to proteolysis (Hynes 1973) and that transformed cells have increased levels of proteases at the cell surface (Unkeless et al 1973). Several of the proteases detected at the surface of transformed cells are also synthesized by normal cells (for review, see Chen \& Chen 1987), but transformation by some viruses may also induce new surface proteases (Chen \& Chen 1987). For example, transformation by Rous sarcoma virus induces novel proteases, which are expressed at sites of adhesion (Chen et al 1984) and degrade FN (Chen et al 1985a).

One protease that has been implicated in the degradation of the ECM both by transformed and normal cells during tissue remodelling is plasmin. This enzyme is widely distributed within the ECM as an inactive precursor, plasminogen, which is converted to plasmin by the protease plasminogen activator. Plasminogen activator and plasmin have been implicated in FN degradation (Quigley 1979; Fairbairn et al 1985). Of considerable significance for the stability of focal adhesions is the discovery that one type of plasminogen activator, urokinase, is concentrated at the extracellular face of these adhesions (Pollanen et al 1987, 1988; Hebert \& Baker 
1988). In most normal cells this enzyme is probably maintained in an inactive state due to the presence of a specific inhibitor. This inhibitor is distributed diffusely beneath cultured cells, including their focal adhesions (Pollanen et al 1987).

The cytoskeletal and adhesive alterations that result from transformation have been extensively studied in RSV-transformed cells. Undoubtedly, the external factors discussed above contribute to the decreased adhesion and altered cytoskeletons in these cells, but there is also evidence that some of the effects of the virus may be exerted directly on the cytoskeleton. Although cells transformed by RSV have reduced focal adhesions, those that persist contain elevated levels of the transforming protein pp60 ${ }^{v-s r c}$ (Rohrschneider 1980). After it was discovered that pp60 ${ }^{v-s r c}$ is a tyrosine-specific protein kinase (Hunter \& Sefton 1980), a search was initiated for potential cytoskeletal substrates for this enzyme. Vinculin was the first cytoskeletal protein shown to contain phosphotyrosine, and the level of phosphotyrosine in vinculin was found to increase significantly following RSV-transformation (Sefton et al 1981). This finding, together with the localization of pp60 $0^{v-s r c}$ within focal adhesions, led to the idea that phosphorylation of target proteins such as vinculin might result in focal adhesion disassembly. Subsequent experiments, however, have not supported this suggestion. Not only is the level of phosphotyrosine in vinculin low, but several studies using viral mutants failed to show a correlation between the level of phosphotyrosine in vinculin and the transformed phenotype (Rohrschneider \& Rosok 1983; Iwashita et al 1983; Antler et al 1985; Rohrschneider \& Reynolds 1985; Kellie et al 1986a,b; Nigg et al 1986). Rosok \& Rohrschneider (1983) investigated whether a transient increase in phosphotyrosine occurs as normal cells disassemble stress fibers upon entering mitosis, but no change in the level of vinculin phosphorylation was detected at any stage in the cell cycle.

These results lead to the conclusion that phosphorylation of vinculin on tyrosine residues is irrelevant to the transformed phenotype; the phosphorylation possibly results from a fortuitous proximity to $\mathrm{pp} 60^{\mathrm{scc}}$, which behaves as a promiscuous kinase. Nevertheless, it could still be argued that only the small population of vinculin found in focal adhesions is relevant and that significant changes in this population are obscured by a large soluble pool. Although it seems unlikely, this possibility gains some credence from experiments with a nontransforming mutant of RSV. This virus synthesizes a nonmyristylated form of pp60 $0^{\mathrm{v}-\mathrm{src}}$, which becomes cytosolic and no longer localizes in focal adhesions (Kamps et al 1986). However, the level of phosphotyrosine in vinculin from cells infected with this virus is higher than that from cells transformed with wild-type RSV (Kamps et al 1986). This suggests that the level of phosphorylation of the 
cytoplasmic pool of vinculin does not affect focal adhesions or stress fibers. The state of phosphorylation of vinculin within the focal adhesion itself is not known. Vinculin is also phosphorylated on serine and threonine residues, but the significance of any of these phosphorylations remains to be determined.

Two other focal adhesion proteins, talin and integrin, also contain elevated phosphotyrosine levels following transformation by RSV (Pasquale et al 1986; Declue \& Martin 1987; Hirst et al 1986). The level of phosphotyrosine in talin, as in vinculin, has not been found to correlate with the transformed phenotype (Declue \& Martin 1987), which suggests that this phosphorylation may also be without consequences. Equivalent studies have not yet been performed on integrin, but it is interesting that integrin, unlike vinculin or talin, is phosphorylated by several tyrosine kinases in addition to pp60 ${ }^{\text {v-src }}$ (Hirst et al 1986). One of the phosphorylation sites occurs on a tyrosine in the cytoplasmic domain of the integrin $\beta$ chain in a sequence that is similar to the autophosphorylation site in the EGF receptor (Hirst et al 1986; Tamkun et al 1986). This tyrosine is in a region involved in talin binding (P. Tapley et al, unpublished observations; Buck \& Horwitz 1987b). Furthermore, integrin isolated from RSV-transformed cells has a decreased affinity for talin (P. Tapley et al, unpublished observations; Buck \& Horwitz 1987b), but it has not been shown whether this is due to phosphorylation or some other modification.

\section{Abnormal "Rosette" Adhesions ("Podosomes") \\ in RSV-transformed Cells}

Cells transformed by RSV and related viruses carrying similar tyrosine kinases frequently reveal abnormal adhesions to the substrate. These were first detected when the distributions of vinculin and $\alpha$-actinin were examined in RSV-transformed fibroblasts (David-Pfeuty \& Singer 1980). Instead of normal focal adhesions, these investigators noted clusters of small adhesions ("rosettes") that often occurred under the nucleus rather than at the periphery like normal focal adhesions. These same structures were detected as aggregates of $\mathrm{F}$-actin when the organization of actin was examined in various transformed cells (Carley et al 1981; Carley \& Webb 1983). Like focal adhesions, rosettes are regions of the cell surface where the plasma membrane comes close to the underlying substrate, generating dark images by IRM. However, these rosette adhesions differ in several ways from the focal adhesions of normal cells. They are much smaller and appear more like protrusions from the ventral cell surface towards the substrate. Because of their footlike morphology they have also been given the name "podosomes" (Tarone et al 1985) [this name has been used previously in another context (Davies \& Stossel 1977)]. Although many of 
the proteins found in focal adhesions have been found in these structures as well (Table 2), immunofluorescence has revealed a protein organization not detected in focal adhesions. Each podosome or rosette adhesion contains a core of actin filaments together with $\alpha$-actinin and fimbrin. The core is surrounded by vinculin and talin, which appear as rings by immunofluorescence microscopy (Burridge \& Connell 1983a,b; Marchisio et al 1984, 1987). Unlike normal focal adhesions, rosette adhesions or podosomes form on naked glass coverslips in the absence of serum (Tarone et al 1985). Perhaps related to this lack of requirement for an ECM, integrin is not usually concentrated within these abnormal adhesions (Chen et al 1986; Giancotti et al 1986) although in a minority of cells it was detected as a diffuse corona of staining around the adhesion (Chen et al 1986).

Compared with focal adhesions, these rosette adhesions or podosomes are much more dynamic structures. Microinjection of fluorescent $\alpha$-actinin into cells transformed by RSV allowed these structures to be observed in living cells (Stickel \& Wang 1987). It was noticed that rosette adhesions incorporated $\alpha$-actinin rapidly and underwent assembly and disassembly within a period of a few minutes. In some cases adjacent adhesions within a cluster moved closer or farther apart. The dy nawics of $\alpha$-actinin within these structures was also studied using fluorescence recovery after photobleaching. This demonstrated a vary rapid turnover of $\alpha$-actinin within

Table 2 Proteins localized in rosette adhesions (podosomes)

Nonnal cells

Virus transfonned cells

(Osteoclasts, macrọphages, monocytes)

Actin $^{\mathrm{a}, \mathrm{b}, \mathrm{c}, \mathrm{d}}$

Vinculin ${ }^{\mathrm{a}, \mathrm{c}, \mathrm{d}}$

Talin $^{\mathrm{b}, \mathrm{d}}$

$\alpha$-Actininina, a,d

Fimbrin $^{c}$

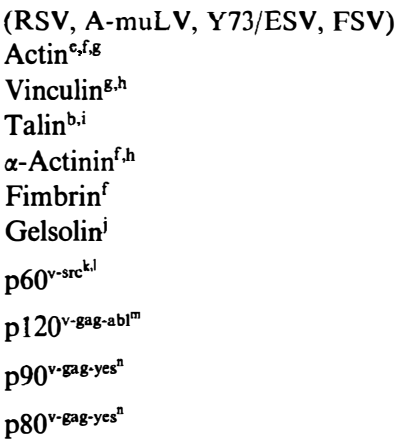

a Lehto et al 1982

b Burridge \& Connell 1983b

${ }^{c}$ Marchisio et al 1984

d Marchisio et al 1987

- Carley et al 1981

'Carley et al 1985

${ }^{8}$ Tarone et al 1985
${ }^{\text {b }}$ David-Pf euty \& Singer 1980

'Burridge \& Connell 1983a

${ }^{j}$ Wang et al 1984

kigg et al 1982

${ }^{1}$ Krueger et al 1984

"n Rohrschneider \& Najita 1984

n Gentry \& Rohrschneider 1984 
a podosome: $50 \%$ of the fluorescence was recovered within a few seconds. In normal focal adhesions the exchange of $\alpha$-actinin was slow: $50 \%$ recovery required more than 5 minutes (Stickel \& Wang 1987). The lack of stability of these structures is interesting and may relate to their low levels of integrin and lack of ECM components. In turn, this absence of ECM components may reflect the increased proteolysis that occurs at these sites (Chen et al 1984) and may involve novel membrane-associated proteases (Chen \& Chen 1987).

Rosette adhesions or podosomes have been detected in many transforrmed cells (Carley et al 1981), but they are most prominent in cells transf ormed by viruses carrying oncogenes encoding tyrosine kinases, such as $\operatorname{src}$ (David-Pfeuty \& Singer 1980), abl (Rohrschneider \& Najita 1984), yes (Gentry \& Rohrschneider 1984), and fps (Tarone et al 1985). The products of the $s r c, a b l$, and yes genes have also been detected in these adhesions (Nigg et al 1982; Krueger et al 1984; Rohrschneider \& Najita 1984; Gentry \& Rohrschneider 1984). Similar (probably identical) structures have been identified in several normal cell types. Aggregates of Factin were detected in spreading macrophages by electron microscopy (Trotter 1981). Using antibodies against actin, $\alpha$-actinin and vinculin, these structures were noted by immunofluorescence in monocytes as they differentiated into macrophages in culture (Lehto et al 1982). Some of the most extensive arrays of these podosomes have been detected in osteoclasts (Marchisio et al 1984, 1987). The significance of these structures and their relationship to focal adhesions is not clear. It is interesting, however, that the normal cells in which they are found tend to be "invasive" and express proteases at their surfaces. It may be that these rosette adhesions or podosomes are normally involved in local degradation of the ECM. Perhaps transformation by RSV and related viruses induces fibroblasts to express the degradative and invasive characteristics normally found in cells such as macrophages and osteoclasts.

\section{SIGNALING}

The ECM influences many aspects of cell behavior, including movement, morphology, differentiation, and proliferation. It seems probable that many of the effects of the ECM are signaled to the cell through its adhesions to the substrate. An example of a complex response initiated by adhesion is platelet activation. Damage to blood vessel walls results in the adhesion of platelets to the exposed subendothelial ECM (George et al 1984). This adhesion, together with the action of agonists such as thrombin, triggers a cascade of events that comprise platelet activation. During this process there is secretion by the platelet of ECM components and factors that 
potentiate platelet adhesion in a positive feedback manner. In addition, activation induces changes in the adhesive properties of the platelet surface that are necessary for platelet aggregation and that allow the platelet integrin, glycoproteins IIb/IIIa, to bind fibrinogen (Shattil et al 1985; Niiya et al 1987). These adhesive events are accompanied by actin polymerization and a change in platelet shape.

Several lines of evidence indicate that the platelet glycoproteins IIb/IIIa may play a role in signal generation through interactions with ion channels. In epinephrine-stimulated platelets it was found that fibrinogen binding to IIb/IIIa appeared to be necessary to maintain the induced $\mathrm{Na}^{+} / \mathrm{H}^{+}$exchange (Banga et al 1986). Glycoproteins IIb/IIIa may also affect calcium homeostasis, as evidenced by platelets from thrombasthenic patients that lack this glycoprotein complex. The influx of calcium is reduced in their platelets by about $50 \%$ (Brass 1985). Calcium influx was similarly perturbed in normal platelets by conditions that dissociated the IIb/IIIa complex (Brass 1985). Conformational changes in the IIb/IIIa complex were induced by ligand binding in vitro (Parise et al 1987). These conformational changes may regulate the interaction of this integrin with other components either in the membrane or at its cytoplasmic face.

If integrins do interact with calcium channels, the high concentration of integrin within focal adhesions may be significant. Calcium fluxes at these sites of adhesion could have many effects. In this respect, it is interesting that one calcium regulated enzyme, the type II isoform of the calciumdependent protease (CDPII) calpain II, has been localized to focal adhesions (Beckerle et al 1987). The function of this enzyme has not been determined, but several cytoskeletal proteins are substrates, and among focal adhesion proteins, talin is particularly susceptible (Collier \& Wang 1982; O'Halloran et al 1985; Beckerle et al 1986). It is easy to envisage schemes in which focal adhesion disassembly is triggered by the calciumdependent proteolysis of talin or other proteins. This hypothesis is being investigated currently, but it is noteworthy that in platelets calcium-dependent proteolysis of talin has been shown to occur physiologically although the significance of this process has not been determined (Fox et al 1985).

Evidence that integrins in other cells may also generate signals in response to binding ECM proteins has come from experiments with monocytes. These cells contain an integrin receptor, Mac-l, for $\mathrm{C}^{3} \mathrm{~b}_{\mathrm{i}}$ (a complement fragment), which under normal conditions mediates attachment of monocytes to erythrocytes coated with $\mathrm{C}_{3} \mathrm{~b}_{\mathrm{i}}$. However, phagocytosis of these $\mathrm{C}_{3} \mathrm{~b}_{\mathrm{i}}$-coated erythrocytes does not occur unless the cells are stimulated with either tumor promoting phorbol esters or substrate-bound fibronectin (Wright \& Silverstein 1982; Wright et al 1983). Presumably the fibronectin binds to a second class of integrin receptors on these 
Table 3 Regulatory proteins in focal adhesions

Extracellular face

Cytoplasmic face

Plasminogen activator (urokinase)

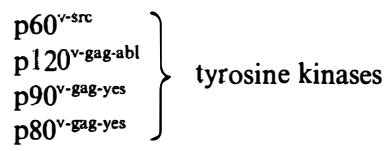

Calcium-dependent protease II

(calpain II)

monocytes. These experiments suggest that under some conditions the binding of integrin to its ECM ligand generates signals equivalent to tumor promoters, possibly via stimulation of protein kinase C. It is important to pursue this signaling pathway further and to determine whether integrins in other situations can generate similar cytoplasmic signals.

The identification of potential regulatory proteins, including viral tyrosine kinases within focal adhesions (Table 3), supports the idea that these regions may be involved in transmembrane signaling. The presence of kinases in the adhesions of cells transformed by particular viruses raises the question of whether equivalent kinases are concentrated within the focal adhesions of normal cells. The level of the homologous tyrosine kinases in nontransformed cells are too low to detect by immunofluorescence microscopy, but elevated levels of phosphotyrosine have been detected in the focal adhesions of normal cells (Maher et al 1985). This striking observation indicates that some tyrosine kinases, quite possibly the homologues of the viral enzymes, are indeed concentrated at the cytoplasmic face of focal adhesions. It is important to determine the functions of the kinases at this site.

\section{FUTURE DIRECTIONS}

In recent years, considerable progress has been made in identifying focal adhesion components and characterizing their interactions. Finding integrins concentrated at these sites has drawn attention to these ECM receptors as critical elements in the transmembrane link between the ECM and the cytoskeleton. Based on binding experiments in vitro, it is possible to construct a chain of proteins linking actin to integrin, but the low affinity of some of these interactions leads us to conclude that other proteins must also function in the attachment of actin filaments to the focal adhesion membrane. New proteins continue to be discovered at focal adhesions. Their identification and the characterization of their interactions are 
necessary for a full understanding of the organization of these structures. A question related to attachment of actin filaments to the membrane is how actin polymerization is regulated at focal adhesions. Little is known about this currently, but it should command attention in years to come. Several regulatory proteins have been identified in focal adhesions and many aspects of cell behavior are determined by cell adhesion to the ECM, which suggests that transmembrane signaling occurs at these sites. The involvement of integrins in generating second messengers at focal adhesions in response to binding ECM components and the nature of the signals thus generated are tantalizing topics for future investigation.

\section{ACKNOWLEDGMENTS}

We thank the following investigators for communicating to us their unpublished results: W. Birchmeier, J. Couchman, D. Critchley, D. DeSimone, J. Feramisco, J. E. B. Fox, B. Geiger, C. Izzard, S. Lin, G. Rinnerthaler, I. I. Singer, S. J. Singer, J. V. Small, and Y.-L. Wang. We greatly appreciate the advice and comments of our colleagues, A. Heggem-Snow, L. Molony, C. Otey, F. Pavalko, and P. Saling. Ms. G. Harrison helped with the artwork. We are indebted to Ms. B. Stewart and Mrs. G. Capers for their patience in preparing several versions of this manuscript. Work in the authors' laboratory was supported by a grant from NIH (GM29860) and the Muscular Dystrophy Association. KF and CT gratef ully acknowledge the support of MDA Postdoctoral Fellowships.

\section{Literature Cited}

Abercrombie, M., Dunn, G. A. 1975. Adhesions of fibroblasts to substratum during contact inhibition observed by interference reflection microscopy. Exp. Cell Res. 92: 57-62

Abercrombie, M., Heaysman, J., Pegrum, S. M. 1971. The locomotion of fibroblasts in culture. Exp. Cell Res. 67: 359-67

Akiyama, S. K., Yamada, S. S., Yamada, K. M. 1986. Characterization of a $140 \mathrm{kd}$ avian cell surface antigen as a fibronectinbinding molecule. J. Cell Biol. 102: 44248

Alexandrova, A. Y., Vasiliev, J. M. 1984. Focal contacts of spreading platelets with the substratum. Exp. Cell Res. 153: 25458

Ali, I. U., Hynes, R. O. 1977. Effects of cytochalasin B and colchicine on attachment of a major surface protein of fibroblasts. Biochim. Biophys. Acta 471: 16-24

Ali, I. U., Mautner, V., Lanza, R. P., Hynes
R. O. 1977. Restoration of normal morphology, adhesion and cytoskeleton in transformed cells by addition of a transformation-sensitive surface protein. Cell 11: 115-26

Anderson, R. A., Marchesi, V. T. 1985. Regulation of the association of membrane skeletal protein 4.1 with glycophorin by a polyphosphoinositide. Nature 318: 295-98

Antler, A. M., Greenberg, M. E., Edelman, G. M., Hanafusa, N. 1985. Increased phosphorylation of tyrosine in vinculin does not occur upon transformation by some avian sarcoma viruses. Mol. Cell. Biol. 5: 263-67

Aubin, J. E., Alders, E., Heersche, J. N. M. 1983. A primary role for microfilaments, but not microtubules, in hormoneinduced cytoplasmic retraction. Exp. Cell Res. 143: 439-50

Avnur, Z., Geiger, B. 1981a. Substrate- 
lation and characterization of ventral membranes and the associated cytoskeleton. J. Mol. Biol. 153: 361-79

Avnur, Z., Geiger, B. 1981 b. The removal of extracellular fibronectin from areas of cellsubstrate contact. Cell 25: 121-32

Avnur, Z., Small, V., Geiger, B. 1983. Actinindependent association of vinculin with the cytoplasmic aspect of the plasma membrane in cell-contact areas. J. Cell Biol. 96: $1622-30$

Badley, R. A., Lloyd, C. W., Woods, A., Carruthers, L., Allcock, C., et al. 1978. Mechanisms of cellular adhesion. Exp. Cell Res. 117: 231-44

Badley, R. A., Woods, A., Smith, C. G., Rees, D. A. 1980. Actomyosin relationships with surface features in fibroblast adhesion. Exp. Cell Res. 126: 263-72

Baetscher, M., Pumplin, D. W., Bloch, R. J. 1986. Vitronectin at sites of cell-substrate contact in cultures of rat myotubes. J. Cell Biol. 103: 369-78

Ball, E. H., Freitag, C., Gurofsky, S. 1986. Vinculin interaction with permeabilized cells: disruption and reconstitution of a binding site. J. Cell Biol. 103: 641-48

Banga, H. S., Simons, E. R., Brass, L. F., Rittenhouse, S. E. 1986. Activation of phospholipases $\mathrm{A}$ and $\mathrm{C}$ in human platelets exposed to epinephrine: role of glycoproteins IIb/IIIa and dual role of epinephrine. Proc. Natl. Acad. Sci. USA 83: 9197-201

Barnes, D. W., Silnutzer, J., See, C., Shaffer, M. 1983. Characterization of human serwn spreading factor with monoclonal antibody. Proc. Natl. Acad. Sci. USA 80: 1362-66

Baron, M. D., Davison, M. D., Jones, P., Critchley, D. R. 1987a. The sequence of chick $\alpha$-actinin reveals homolgies to spectrin and calmodulin. J. Biol. Chem. 262: 17623-29

Baron, M. D., Davison, M. D., Jones, P., Paltel, B., Critchley, D. R. 1987b. Isolation and characterization of a cDNA encoding a chick $\alpha$-actinin. J. Biol. Chem. 262: 2558-61

Beckerle, M. C. 1986. Identification of a new protein localized at sites of cell-substrate adhesion. J. Cell Biol. 103: 1679-87

Beckerle, M. C., Burridge, K., DeMartino, G. N., Croall, D. E. 1987. Colocalization of calcium-dependent protease II and one of its substrates at sites of cell adhesion. Cell 51: 569-77

Beckerle, M. C., O'Halloran, T., Burridge, K. 1986. Demonstration of a relationship between talin and P235, a major substrate of the calcium-dependent protease in platelets. J. Cell. Biochem. 30: 259-70
Burridge, K. 1985. Evidence for functional similarities between talin and platelet P235. J. Cell Biol. 101: 411a

Belkin, A. M., Koteliansky, V. E. 1987. Interaction of iodinated vinculin, metavinculin and $\alpha$-actinin with cytoskeletal proteins. FEBS Lett. 220: 291-94

Bennett, J. P., Zaner, K. S., Stossel, T. P. 1984. Isolation and some properties of macrophage $\alpha$-actinin: evidence that it is not an actin gelling protein. Biochemistry 23: 5081-86

Bennett, J. S., Vilaire, G. 1979. Exposure of platelet fibrinogen receptors by ADP and epinephrine. J. Clin. Invest. 64: 1393-1401

Bereiter-Hahn, J., Fox, C. H., Thorell, B. 1979. Quantitative reflection contrast microscopy of living cells. J. Cell Biol. 82: 767-79

Bershadsky, A. D., Tint, I. S., Neyfakh, A. A., Vasiliev, J. M. 1985. Focal contacts of normal and RSV-transformed quail cells. Exp. Cell Res. 158: 433-44

Bershadsky, A. D., Tint, I. S., Svitkina, J. M. 1987. Association of intermediate filaments with vinculin-containing adhesion plaques of fibroblasts. Cell Motil. Cytoskel. 8: 274-83

Beyth, R. C., Culp, L. A. 1984. Complementary adhesive responses of human skin fibroblasts to the cell-binding domain of fibronectin and the heparan sulfatebinding protein, platelet factor 4. Exp. Cell Res. 155: 537-48

Birchmeier, C., Kreis, T. E., Eppenberger, H. M., Winterhalter, K. H., Birchmeier, W. 1980. Corrugated attachment membrane in WI-38 fibroblasts. Alternating fibronectin fibers and actin-containing focal contacts. Proc. Natl. Acad. Sci. USA 77: 4108-12

Bloch, R. J., Hall, Z. W. 1983. Cytoskeletal components of the vertebrate neuromuscular junction. J. Cell Biol. 97: 217-23

Bogaert, T., Brown, N., Wilcox, M. 1987. The Drosophila PS2 antigen is an invertebrate integrin that, like the fibronectin receptor, becomes localized to muscle attachments. Cell 51: 929-40

Branton, D., Cohen, C., Tyler, J. 1981. Interaction of cytoskeletal proteins on the human red cell membrane. Cell 24: 24-32

Brass, L. F. 1985. $\mathrm{Ca}^{2+}$ transport across the platelet plasma membrane: a role for membrane glycoproteins IIB and IIIa. $J$. Biol. Chem. 260: 2231-36

Bretscher, A. 1981. Fimbrin is a cytoskeletal protein that cross-links F-actin in vitro. Proc. Natl. Acad. Sci. USA 78: 6849-53

Bretscher, A., Weber, K. 1980. Fimbrin, a new microfilament-associated protein 
present in microvilli and other cell surt ace

structures. J. Cell Biol. 86: 335-40

Brown, P. J., Juliano, R. L. 1985. Selective inhibition of fibronectin-mediated cell adhesion by monoclonal antibodies to a cell surface glycoprotein. Science 228: 1448-51

Buck, C. A., Horwitz, A. F. 1987a. Cell surface receptors for extracellular matrix molecules. Ann. Rev. Cell Biol. 3: 179-205

Buck, C. A., Horwitz, A. F. 1987b. Integrin, a transmembrane glyoprotein complex mediating cell-substratum adhesion. $J$. Cell Sci. Suppl. 8: 231-50

Burn, P., Kupfer, A., Singer, S. J. 1988. Dynamic membrane-cytoskeletal interactions: specific association of integrin and talin arises in vivo after phorbol ester treatment of peripheral blood lymphocytes. Proc. Natl. Acad. Sci. USA 85: 497501

Burn, P., Rotman, A., Meyer, R. K., Burger, M. M. 1985. Diacylglycerol in large $\alpha$-actinin/actin complexes and in the cytoskeleton of activated platelets. Nature 314: 469-71

Burridge, K. 1981. Are stress fibers contractile? Nature 294: 691-92

Burridge, K. 1986. Substrate adhesions in normal and transformed fibroblasts: organization and regulation of cytoskeletal, membrane and extracellular matrix components at focal contacts. $C$ ancer Rev. 4: 18-78

Burridge, K., Connell, L. 1983a. A new protein of adhesion plaques and ruffling membranes. J. Cell Biol. 97: 359-67

Burridge, K., Connell, L. 1983b. Talin: a cytoskeletal component concentrated in adhesion plaques and other sites of actinmembrane interaction. Cell Motil. 3: 40517

Burridge, K., Feramisco, J. R. 1980. Microinjection and localization of a $130 \mathrm{k}$ protein in living fibroblasts: a relationship to actin and fibronectin. Cell 19: 587-95

Burridge, K., Feramisco, J. R. 1981. Nonmuscle $\alpha$-actinins are calcium-sensitive actin-binding proteins. Nature 294: 56567

Burridge, K., Feramisco, J. R. 1982. $\alpha$-actinin and vinculin from non-muscle cells: calcium-sensitive interactions with actin. Cold Spring Harbor Symp. Quant. Biol. 46: 587-97

Burridge, K., Mangeat, P. 1984. An interaction between vinculin and talin. Nature 308: 744-46

Byers, H. R., White, G. E., Fugiwara, K. 1984. Organization and function of stress fibers in cells in vitro and in situ. Cell Muscle Motil. 5: 83-137

Carley, W. W., Barak, L. S., Webb, W. W. cells. J. Cell Biol. 97: 797-802

Carley, W. W., Bretscher, A., Webb, W. W. 1985. F-actin aggregates in transformed cells contain $\alpha$-actinin and fimbrin but apparently lack tropomyosin. Eur. J. Cell Biol. 39: 313-20

Carley, W. W., Webb, W. W. 1983. F-actin aggregates may activate transformed cell surfaces. Cell Motil. 3: 383-90

Cathcart, M. K., Culp, L. A. 1979. Initial studies of the molecular organization of the cell-substrate adhesion site. Biochim. Biophys. Acta 556: 331-43

Chapman, A. E. 1984. Characterization of a $140 \mathrm{kd}$ cell surface glycoprotein involved in myoblast adhesion. J. Cell. Biochem. 25: 109-21

Chen, J.-M., Chen, W.-T. 1987. Fibronectindegrading proteases from the membranes of transf ormed cells. Cell 48: 193-203

Chen, W.-T., Chen, J.-M., Parsons, S. J., Parsons, J. T. 1985a. Local degradation of fibronectin at sites of expression of the transforming gene product $\mathrm{pp} 60^{\mathrm{scc}}$. Nature 316: $156-58$

Chen, W.-T., Hasegawa, E., Hasegawa, T., Weinstock, C., Yamada, K. M. 1985b. Development of cell surface linkage complexes in cultured fibroblasts. J. Cell Biol. 100: 1103-14

Chen, W.-T., Olden, K., Bernard, B. A., Chu, F. 1984. Expression of transformation-associated protease(s) that degrade fibronectin at cell contact sites. $J$. Cell Biol. 98: 1546-55

Chen, W.-T., Singer, S. J. 1980. Fibronectin is not present in the focal adhesions formed between normal cultured fibroblasts and their substrata. Proc. Natl. Acad. Sci. USA 77: 7318-22

Chen, W.-T., Singer, S. J. 1982. Immunoelectron microscopic studies of the sites of substratum and cell-cell contacts in cultured fibroblasts. J. Cell Biol. 95: 205-22

Chen, W.-T., Wang, J., Hasegawa, T., Yamada, S. S., Yamada, K. M. 1986. Regulation of fibronectin receptor distribution by transformation, exogenous fibronectin, and synthetic peptides. J. Cell Biol. 103: 1649-61

Collier, N. C., Wang, K. 1982. Purification and properties of human platelet P235. $J$. Biol. Chem. 257: 6937-43

Cheresh, D. A. 1987. Human endothelial cells synthesize and express an Arg-GlyAsp-directed adhesion receptor involved in attachment to fibrinogen and von Willebrand factor. Proc. Natl. Acad. Sci. USA 84: 6471-75

Cheresh, D. A., Spiro, R. C. 1987. Biosynthetic and functional properties of an Arg- 
human melanoma cell attachment to vitronectin, fibrinogen, and von Willebrand factor. J. Biol. Chem. 262: 1770311

Couchman, J. R., Rees, D. A. 1979. The behavior of fibroblasts migrating from chick heart explants: changes in adhesion, locomotion and growth, and in the distribution of actomyosin and fibronectin. J. Cell Sci. 39: 149-65

Couchman, J. R., Rees, D. A., Green, M. R., Smith, C. G. 1982. Fibronectin has a dual role in locomotion and anchorage of primary chick fibroblasts and can promote entry into the division cycle. J. Cell Biol. 93: 402-10

Craig, S. W. 1985. Alpha-actinin, an F-actin cross-linking protein, interacts directly with vinculin and meta-vinculin. $J$. Cell Biol. 101: 136a

Curtis, A. S. G. 1964. The mechanism of adhesion of cells to glass. A study by interference reflection microscopy. J. Cell Biol. 20: $199-215$

Damsky, C. H., Knudsen, K. A., Bradley, D., Buck, C. A., Horwitz, A. F. 1985. Distribution of the cell substratum attachment (CSAT) antigen on myogenic and fibroblastic cells in culture. J. Cell Biol. 100: 1528-39

David-Pf euty, T., Singer, S. J. 1980. Altered distributions of the cytoskeletal proteins vinculin and $\alpha$-actinin in cultured fibroblasts transformed by Rous sarcoma virus. Proc. Natl. Acad. Sci. USA 77: 6687-91

Davies, W. A., Stossel, T. P. 1977. Peripheral hyaline blebs (podosomes) of macrophages. J. Cell Biol. 75: 941-55

DeClue, J. E., Martin, G. S. 1987. Phosphorylation of talin at tyrosine in Rous sarcoma virus-transformed cells. Mol. Cell. Biol. 7: 371-78

DePasquale, J. A., Izzard, C. S. 1987. Evidence for an actin-containing cytoplasmic precursor of the focal contact and the timing of incorporation of vinculin at the focal contact. J. Cell Biol. 105: 2803-9

DeSimone, D. W., Hynes, R. O. 1988. Xenopus laevis integrins: structural conservation and evolutionary divergence of integrin $\beta$ subunits. J. Biol. Chem. 263: 5333-40

Drenckhahn, D., Beckerle, M., Burridge, K., Otto, J. 1988. Identification and subcellular location of talin in various cell types and tissues by means of vinculin overlay, immunoblotting and immunocytochemistry. Eur. J. Cell Biol. In press

Evans, R. R., Robson, R. M., Stromer, M. H. 1984. Pioperties of smooth muscle vinculin. J. Biol. Chem. 259: 3916-24
Schwimmer, R., Quigley, J. P. 1985. The extracellular matrix of normal chick embryo fibroblasts: its effect on transformed chick fibroblasts and its proteolytic degradation by the transformants. J. Cell Biol. 101: 1790-98

Feramisco, J. R., Burridge, K. 1980. A rapid purification of $\alpha$-actinin, filamin, and a 130,000-dalton protein from smooth muscle. J. Biol. Chem. 255: 1194-99

Fox, J. E. B., Goll, D. E., Reynolds, C. C., Phillips, D. R. 1985. Identification of two proteins (actin-binding protein and P235) that are hydrolyzed by endogenous $\mathrm{Ca}^{2+}$. dependent protease during platelet aggregation. J. Biol. Chem. 260: 1060-66

Gardner, J. M., Hynes, R. O. 1985. Interaction of fibronectin with its receptor on platelets. Cell 42: 439-48

Geiger, B. 1979. A $130 \mathrm{~K}$ protein from chicken gizzard: its localization at the termini of microfilament bundles in cultured chicken cells. Cell 18: 193-205

Geiger, B. 1982. Microheterogeneity of avian and mammalian vinculin. Distinctive subcellular distribution of different isovinculins. J. Mol. Biol. 159: 685701

Geiger, B., Avnur, Z., Kreis, T. E., Schlessinger, J. 1984a. The dynamics of cytoskeletal organization in areas of cell contact. Cell Muscle Motil. 5: 195234

Geiger, B., Avnur, Z., Rinnerthaler, G., Hinssen, H., Small, V. J. 1984b. Microfilament-organizing centers in areas of cell contact: cytoskeletal interactions during cell attachment and locomotion. J. Cell Biol. 99: 83-91

Geiger, B., Avnur, Z., Schlessinger, J. 1982. Restricted mobility of membrane constituents in cell substrate focal contacts of chicken fibroblasts. J. Cell Biol. 93: 495500

Geiger, B., Dutton, A. H., Tokuyasu, K. T., Singer, S. J. 1981. Immunoelectron microscope studies of membrane-microfilament interactions: distribution of $\alpha$-actinin, tropomyosin and vinculin in intestinal brush border and chicken gizzard smooth muscle cells. J. Cell Biol. 91: 614-28

Geiger, B., Tokuyasu, K. T., Dutton, A. H., Singer, S. J. 1980. Vinculin, an intracellular protein localized at specialized sites where microfilament bundles terminate at cell membranes. Proc. Natl. Acad. Sci. USA 77: 4127-31

Geiger, B., Volk, T., Volberg, T. 1985. Molecular heterogeneity of adherens junctions. J. Cell Biol. 101: 1523-31

Gentry, L. E., Rohrschneider, L. R. 1984. Common features of the yes and src gene 
products defined by peptide-specific antibodies. J. Virol. 51: 539-46

George, J. N., Norden, A. T., Phillips, D. R. 1984. Molecular defects in interactions of platelets with the vessel wall. $N$. Engl. $J$. Med. 311: 1084-98

Giancotti, F. G., Comoglio, P. M., Tarone, G. 1986. A 135,000 molecular weight plasma membrane glycoprotein involved in fibronectin-mediated cell adhesion. Exp. Cell Res. 163: 47-62

Giancotti, F. G., Languino, L. R., Zanetti, A., Peri, G., Tarone, G., et al. 1987. Platelets express a membrane protein complex immunologically related to the fibroblast fibronectin receptor and distinct from GPIIb/IIIa. Blood 69: 1535-38

Giancotti, F. G., Tarone, G., Knudsen, K., Damsky, C., Comoglio, D. M. 1985. Cleavage of a $135 \mathrm{kd}$ cell surface glycoprotein correlates with loss of fibroblast adhesion to fibronectin. Exp. Cell Res. 156: $182-90$

Gimona, M., Furst, D. O., Small, J. V. 1987. Metavinculin and vinculin from mammalian smooth muscle: bulk isolation and characterization. J.Musc. Res. Cell Motil. 8: 329-41

Gingell, D. 1981. The interpretation of interference-reflection images of spread cells: significant contribution from thin peripheral cytoplasm. J. Cell Sci. 49: 237-47

Ginsberg, M. H., Forsyth, J., Lightsey, A., Chediak, J., Plow, E. F. 1983. Reduced surface expression and binding of fibronectin by thrombin-stimulated thrombasthenic platelets. J. Clin. Invest. 71: 619-24

Green, K. J., Goldman, R. D. 1986. Evidence for an interaction between the cell surface and intermediate filaments in cultured fibroblasts. Cell Motil. Cytoskel. 6: 389-405

Greve, J. M., Gottlieb, D. I. 1982. Monoclonal antibodies which alter the morphology of cultured chick myogenic cells. J. Cell. Biochem. 18: 221-29

Grinnell, F. 1980. Visualization of cell substratum adhesion plaques by antibody exclusion. Cell Biol. Int. Rep. 4: 1031-36

Grinnell, F. 1986. Focal adhesion sites and the removal of substratum-bound fibronectin. J. Cell Biol. 103: 2697-2706

Grinnell, F., Feld, M. K. 1979. Initial adhesion of human fibroblasts in serumfree medium: possible role of secreted fibronectin. Cell 17: 117-29

Hasegawa, T., Hasegawa, E., Chen, W.-T., Yamada, K. M. 1985. Characterization of a membrane-associated glycoprotein complex implicated in cell adhesion to fibronectin. J. Cell. Biochem. 28: 307-18

Hayman, E. G., Pierschbacher, M. D., Ön- gren, Y., Ruoslahti, E. 1983. Serum spreading factor (vitronectin) is present at the cell surface and in tissues. Proc. Natl. Acad. Sci. USA 80: 4003-7

Hayman, E. G., Pierschbacher, M. D., Suzuki, S., Ruoslahti, E. 1985. Vitronectin-a major cell attachment-promoting protein in fetal bovine serum. Exp. Cell Res. 160: 245-58

Heath, J. P., Dunn, G. A. 1978. Cell to substratum contacts of chick fibroblasts and their relation to the microfilament system. A correlated interference-reflexion and high voltage electron-microscope study. $J$. Cell Sci. 29: 197-212

Hebert, C. A., Baker, J. B. 1988. Linkage of extracellular plasminogen activator to fibroblast cytoskeleton: colocalization of cell surface urokinase with vinculin. J. Cell Biol. 106: 1241-47

Herman, B., Harrington, M. A., Olashaw, N. E., Pledger, W. J. 1986. Identification of the cellular mechanisms responsible for platelet-derived growth factor induced alterations in cytoplasmic vinculin distribution. J. Cell Physiol. 126: 115-25

Herman, B., Pledger, W. J. 1985. Plateletderived growth factor-induced alterations in vinculin and actin distribution in BALB/c-3T3 cells. J. Cell Biol. 100: 103140

Herman, B., Roe, M. W., Harris, C., Wray, B., Clemmons, D. 1987. Platelet-derived growth factor-induced alterations in vinculin distribution in porcine vascular smooth muscle cells. Cell Motility Cytoskel. 8: 91-105

Herman, I. M., Crisona, N. J., Pollard, T. D. 1981. Relation between cellactivity and the distribution of cytoplasmic actin and myosin. J. Cell Biol. 90: 84-91

Hirst, R., Horwitz, A., Buck, C., Rohrschneider, L. 1986. Phosphorylation of the fibronectin receptor complex in cells transformed by oncogenes that encode tyrosine kinases. Proc. Natl. Acad. Sci. USA 83: 6470-74

Holmes, R. 1967. Preparation from human serum of an alpha-one protein which induces immediate growth of unadapted cells in vitro. J. Cell Biol. 32: 297-308

Horwitz, A., Duggan, K., Buck, C., Beckerle, M. C., Burridge, K. 1986. Interactions of plasma membrane fibronectin receptor with talin-a transmembrane linkage. Nature 320: 531-33

Horwitz, A., Duggan, K., Greggs, R., Decker, C., Buck, C. 1985. The CSAT antigen has properties of a receptor for laminin and fibronectin. J. Cell Biol. 101: 2134-44

Hunter, T., Sefton, B. M. 1980. The transforming gene product of Rous sarcoma 
virus phosphorylates tyrosine. Proc. Natl. Acad. Sci. USA 77: 1311-15

Hynes, R. O. 1973. Alteration of cell-surface proteins by viral transformation and by proteolysis. Proc. Natl. Acad. Sci. USA 70: 3170-74

Hynes, R. O. 1987. Integrins: a family of cell surface receptors. Cell 48: 549-54

Hynes, R. O., DeSimone, D. W., Lawler, J. J., Marcantonio, E. E., Norton, P. A., et al. 1988. Nectins and integrins: versatility in cell adhesion. In The Cell in Contact, ed. G. M. Edelman, E. Gall, Vol. 2. New York: Wiley. In press

Iwashita, S., Kitamura, N., Yoshida, M. 1983. Molecular events leading to fusiform morphological transformation by partial src deletion mutant of Rous sarcoma virus. Virology 125: 419-31

Izzard, C. S. 1988. A precursor of the focal contact in cultured fibroblasts. Cell Motil. Cytoskel. In press

Izzard, C. S., Lochner, L. R. 1976. Cell-tosubstrate contacts in living fibroblasts: an interference reflexion study with an evaluation of the technique. J.CellSci.21: 12959

Izzard, C. S., Lochner, L. R. 1980. Formation of cell-to-substrate contacts during fibroblast motility: an interferencereflexion study. J. Cell Sci. 42: 81-116

Izzard, C. S., Radinsky, R., Culp, L.A. 1986. Substratum contacts and cytoskeletal reorganization of Balb/c3T3 cells on a cellbinding fragment and heparin-binding fragments of plasma fibronectin. Exp. Cell Res. 165: 320-36

Jockusch, B. M., Isenberg, G. 1981. Interaction of $\alpha$-actinin and vinculin with actin: opposite effects on filament network formation. Proc. Natl. Acad. Sci. USA 78: 3005-9

Kamps, M. P., Buss, J. E., Sefton, B. M. 1986. Rous sarcoma virus transforming protein lacking myristic acid phosphorylates known polypeptide substrates without inducing transformation. Cell 45: 105-12

Kellie, S., Holme, T. C., Bissell, M. J. 1985. Interaction of tumor promoters with epithelial cells in culturè: an immunofluorescence study. Exp. Cell Res. 160: 25974

Kellie, S., Patel, B., Mitchell, A., Critchley, D. R., Wigglesworth, N. M., et al. 1986a. Comparison of the relative importance of tyrosine-specific vinculin phosphorylation and the loss of surface-associated fibronectin in the morphology of cells transformed by Rous sarcoma virus. J. Cell Sci. 82: 129-42

Kellie, S., Patel, B., Wigglesworth, N. M., Critchley, D. R., Wyke, J. A. 1986b. The use of Rous sarcoma virus transformation mutants with differing tyrosine kinase activities to study the relationship between vinculin phosphorylation, pp $60^{\mathrm{src}}$ location and adhesion plaque integrity. Exp. Cell Res. 165: 216-28

Kelly, T., Molony, L:, Burridge, K. 1987. Purification of two smooth muscle glycoproteins related to integrin: distribution in cultured chicken embryo fibroblasts. $J$. Biol. Chem. 262: 17189-99

Kishimoto, T. K., O’Connor, K., Lee, A., Roberts, T. M., Springer, T. A. 1987. Cloning the $\beta$ subunit of the leukocyte adhesion proteins: homology to an extracellular matrix receptor defines a novel supergene family. Cell 48: 681-90

Kjellen, L., Pettersson, I., Hook, M. 1981. Cell-surface heparan sulfate: an intercalated membrane proteoglycan. Proc. Natl. Acad. Sci. USA 78: 5371-75

Knudsen, K. A., Horwitz, A. F., Buck, C. A. 1985. A monoclonal antibody identifies a glycoprotein complex involved in cellsubstratum adhesion. Exp. Cell Res. 157: 218-26

Kolega, J., Shure, M. S., Chen, W., Young, N. D. 1982. Rapid cellular translocation is related to close contacts formed between various cultured cells and their substrata. J. Cell Sci. 54: 23-34

Koteliansky, V. E., Gneushev, G. N., Belkin, A. M. 1985. Purification of a 175-kDa membrane protein, its localization in smooth and cardiac muscles. FEBS Lett. 182: 67-72

Koteliansky, V. E., Gneushev, G. N., Glukhova, M. A., Vergaminov, S. Y., Muszbeck, L. 1984. Identification and isolation of vinculin from platelets. FEBS Lett. 165: 26-30

Kreis, T. E., Geiger, B., Schlessinger, J. 1982. Mobility of microinjected rhodamine actin within living chicken gizzard cells determined by fluorescence photobleaching recovery. Cell 29: $835-45$

Krueger, J. G., Garber, E. A., Chin, S. S.M., Hanaf usa, H., Goldberg, A. R. 1984. Size-variant pp $60^{\text {src }}$ proteins of recovered avian sarcoma viruses interact with adhesion plaques as peripheral membrane proteins: effects on cell transformation. Mol. Cell. Biol. 4: 454-67

Kupfer, A., Singer, S. J., Dennert, G. 1986. On the mechanism of uni-directional killing in mixtures of two cytotoxic T-lymphocytes. J. Exp. Med. 163: 489-98

Kupfer, A., Swain, S. L., Singer, S. J. 1987. The specific direct interaction of helper $T$ cells and antigen-presenting $B$ cells. II Reorientation of the microtubule organizing center and reorganization of the membrane-associated cytoskeleton inside 
the bound helper

165: 1565-80

Kurkinen, M., Wartiovaara, J., Vaheri, A. 1978. Cytochalasin B releases a major surface-associated glycoprotein, fibronectin, from cultured fibroblasts. Exp. Cell Res. 111: 127-37

Lamb, N. J. C., Fernandez, A., Conti, M., Adelstein, R., Glass, D. B., et al. 1988. Regulation of actin microfilament integrity in living nonmuscle cells by the cAMP. dependent protein kinase and the myosin light chain kinase. J. Cell Biol. 106: 1955-71

Lark, M. W., Culp, L. A. 1984. Multiple classes of heparan sulfate proteoglycans from fibroblast substratum adhesion sites. Affinity fractionation on columns of platelet factor 4, plasma fibronectin, and octylsepharose. J. Biol. Chem. 259: 6773-82

Lark, M. W., Laterra, J., Culp, L. A. 1985. Close and focal contact adhesions of fibroblasts to a fibronectin-containing matrix. Fed. Proc. 44: 394-403

Laterra, J., Ansbacher, R., Culp, L. A. 1980. Glycosaminoglycans that bind cold-insoluble globulin in cell-substratum adhesion sites of murine fibroblasts. Proc. Natl. Acad. Sci. USA 77: 6662-66

Laterra, J., Norton, E. K., Izzard, C. S., Culp, L. A. 1983. Contact formation by fibroblasts adhering to heparan sulfatebinding substrata (fibronectin or platelet factor 4). Exp. Cell Res. 146: 15-27

Lawrence, T. S., Ginzberg, R. D., Gilula, N. B., Beers, W. H. 1979. Hormonally induced cell shape changes in cultured rat ovarian granulosa cells. J. Cell Biol. 80: 21-36

Lazarides, E., Burridge, K. 1975. $\alpha$-actinin: immunofluorescent localization of a muscle structural protein in nonmuscle cells. Cell 6: 289-98

Leader, W. M., Stopak, D., Harris, A. K. 1983. Increased contractile strength and tightened adhesions to the substratum result from reverse transformation of CHO cells by dibutyryl cyclic adenosine monophosphate. J. Cell Sci., 64: 1-11

LeBaron, R. G., Esko, J. D., Woods, A., Johansson, S., Hook, M. 1988. Adhesion of glycosaminoglycan-deficient Chinese hamster ovary cell mutants to fibronectin substrata. J. Cell Biol. 106: 945-52

Lehto, V. P., Hovi, T., Vartio, T., Badley, R. A., Virtanen, I. 1982. Reorganization of cytoskeletal and contractile elements during transition of human monocytes into adherent macrophages. Lab. Invest. 47: 391-99

Leptin, M., Aebersold, R., Wilcox, M. 1987. Drosophila position-specific antigens resemble the vertebrate fibronectic-receptor family. $E M B O J$ J. 6: 1037-43 phorylation of the cytoskeletal protein talin by protein kinase C. Biochem. Biophys. Res. Comm. 134: 1276-83

Maher, P. A., Pasquale, E. B., Wang, J. Y. J., Singer, S. J. 1985. Phosphotyrosinecontaining proteins are concentrated in focal adhesions and intercellular junctions in normal cells. Proc. Natl. Acad. Sci. USA 82: $6576-80$

Maher, P., Singer, S. J. 1983. A 200-kd protein isolated from the fascia adherens membrane domains of chicken cardiac muscle cells is detected immunologically in fibroblast focal adhesions. Cell Motil. 3: 419-29

Marcantonio, E. E., Hynes, R. O. 1988. Antibodies to the conserved cytoplasmic domain of the integrin $\beta_{1}$ subunit react with proteins in vertebrates, invertebrates and fungi. J. Cell Biol. 106: 1765-72

Marchisio, P. C., Cirillo, D., Naldini, L., Primavera, M. V., Teti, A., et al. 1984. Cell-substratum interaction of cultured avian osteoclasts is mediated by specific adhesion structures. J. Cell Biol. 99: 16961705

Marchisio, P. C., Cirillo, D., Teti, A., Zambonin-Zallone, A., Tarone, G. 1987. Rous sarcoma virus-transformed fibroblasts and cells of monocytic origin display a peculiar dot-like organization of cytoskeletal proteins involved in microfilament-membrane interactions. Exp. Cell Res. 169: 202-14

Matsudaira, P. T., Burgess, D. R. 1979. Identification and organization of the components in the isolated microvillus cytoskeleton. J. Cell Biol. 83: 667-73

Meigs, J. B., Wang, Y.-L. 1986. Reorganization of alpha-actinin and vinculin induced by a phorbol ester in living cells. J. Cell Biol. 102: 1430-38

Milam, L. M. 1985. Electron microscopy of rotary shadowed vinculin and vinculin complexes. J. Mol. Biol. 184: 543-45

Molony, L., Kelly, T., Burridge, K. 1987a. Does integrin bind actin directly? J. Cell Biol. 105: 177a

Molony, L., McCaslin, D., Abernethy, J., Paschal, B., Burridge, K. 1987b. Purification and characterization of talin from chicken gizzard smooth muscle. J. Biol. Chem. 262: 7790-95

Mueller, S. C., Hasegawa, T., Yamada, S. S., Yamada, K. M., Chen, W.-T. 1988. Transmembrane orientation of the fibronectin receptor complex (integrin) demonstrated directly by a combination of immunocytochemical approaches. $J$. Histochem. Cytochem. 36: 297-306

Neff, N. T., Lowrey, C., Decker, C., Tovar, A., Damsky, C., et al. 1982. A monoclonal 
muscle from extracellular matrices. J. Cell Biol. 95: 654-66

Neyfakh, A. A., Svitkina, T. M. 1983. Isolation of focal contact membrane using saponin. Exp. Cell Res. 149: 582-86

Neyfakh, A. A., Tint, I. S., Svitkina, T. M., Bershadsky, A. D., Gelfand, V. I. 1983. Visualization of cellular focal contacts using a monoclonal antibody to $80 \mathrm{kd}$ serum protein adsorbed on the substratum. Exp. Cell Res. 149: 387-96

Nicol, A., Nermut, M. V. 1987. A new type of substratum adhesion structure in NRK cells revealed by correlated interference reflection and electron microscopy. Eur. J. Cell Biol. 43: 348-57

Nigg, E. A., Sefton, B. M., Hunter, T., Walter, G., Singer, S. J. 1982. Immunofluorescent localization of the transforming protein of Rous sarcoma virus with antibodies against a synthetic src peptide. Proc. Natl. Acad. Sci.USA 79: 5322 26

Nigg, E. A., Sefton, B. M., Singer, S. J., Vogt, P. K. 1986. Cytoskeletal organization, vinculin-phosphorylation, and fibronectin expression in transformed fibroblasts with different cell morphologies. Virology 151: 50-65

Niiya, K., Hodson, E., Bader, R., ByersWard, V., Koziol, J. A., et al. 1987. Increased surface expression of the membrane glycoprotein IIb/IIIa complex induced by platelet activation. Relationship to the binding of fibrinogen and platelet aggregation. Blood 70: 475-83

Norrild, B., Virtanen, I., Lehto, V. P., Pedersen, B. 1983. Accumulation of Herpes Simplex virus Type I Glycoprotein D in adhesion areas of infected cells. J. Gen. Virol. 64: 2499-2503

Oesch, B., Birchmeier, W. 1982. New surface component of fibroblast's focal contacts identified by a monoclonal antibody. Cell 31: $671-79$

O’Halloran, T., Beckerle, M. C., Burridge, K. 1985. Identification of talin as a major cytoplasmic protein implicated in platelet activation. Nature 317: 449-51

Olden, K., Yamada, K. M. 1977. Mechanism of the decrease in the major cell surface protein of chick embryo fibroblasts after transformation. Cell 11: 957-69

Otto, J. J. 1983. Detection of vinculin-binding proteins with an ${ }^{125} \mathrm{I}$-vinculin gel overlay technique. J. Cell Biol. 97: 128387

Otto, J. J. 1986. The lack of interaction between vinculin and actin. Cell Motil. Cytoskel. 6: 48-55

Painter, R. G., Prodouz, K. N., Gaarde, W. 1985. Isolation of a subpopulation of glycoprotein IIb-IIIa from platelet mem-
J. Cell Biol. 100: 652-57

Parise, L. V., Helgerson, S. L., Steiner, B., Nannizzi, L., Phillips, D. R. 1987. Synthetic peptides from fibrinogen and fibronectin change the conformation of purified platelet glycoprotein IIb-IIIa. $\boldsymbol{J}$. Biol. Chem. 262: 12597-12604

Parise, L. V., Phillips, D. R. 1986. Fibronectin-binding properties of the purified glycoprotein IIb-IIIa complex. J. Biol. Chem. 261: 14011-17

Pasquale, E. B., Maher, P. A., Singer, S. J. 1986. Talin is phosphorylated on tyrosine in chicken embryo fibroblasts transf ormed by Rous sarcoma virus. Proc. Natl. Acad. Sci. USA 83: 5507-11

Pastan, I., Willingham, M. 1978. Cellular transformation and the morphologic phenotype of transformed cells. Nature 274: $645-50$

Piotrowicz, R. S., Orchekowski, R. P., Nugent, D. J., Yamada, K. Y., Kunicki, T. J. 1988. Glycoprotein Ic-IIa functions as an activator-independent fibronectin receptor on human platelets. J. Cell Biol. 106: 1359-64

Pischel, K. D., Bluestein, H. G., Woods, V. L. 1988. Platelet glycoproteins Ia, Ic and IIa are identical to the VLA adhesionrelated proteins of lymphocytes and other cell types. J. Clin. Invest. 81: 505-13

Pledger, W. J., Stiles, C. D., Antoniades, H. N., Scher, C. D. 1977. Induction of DNA synthesis in BALB/C-3T3 cells by serum components: reevaluation of the commitment process. Proc. Natl. Acad. Sci. USA 74: 4481-85

Plow, E. F., McEver, R. P., Collier, B. S., Woods, V. L. Jr., Marguerie, G. A., et al. 1985. Related binding mechanisms for fibrinogen, fibronectin, von Willebrand factor and thrombospondin on thrombinstimulated human platelets. Blood 66: 724-27

Pollanen, J., Hedman, K., Nielsen, L. S., Dano, K., Vaheri, A. 1988. Ultrastructural localization of plasma membrane-associated urokinase-type plasminogen activator at focal contacts. J. Cell Biol. 106: 87-95

Pollanen, J., Saksela, O., Salonen, E.-M., Andreasen, P. A., Nielsen, L.-S., et al. 1987. Distinct localizations of urokinasetype plasminogen activator and its inhibitor under cultured human fibroblasts and sarcoma cells. J. Cell Biol. 104: 1085-96

Price, G. J., Jones, P., Davison, M. D., Patel, B., Eperon, I. C., et al. 1987. Isolation and coharacterization of a vinculin cDNA from cchick-embryo fibroblasts. Biochem. J. 245: $5595 \div 603$

Pyłtéla; R., Pierschbacher, M. D., Ginsberg, 
M. H., Plow, E. F., Ruoslahti, E. 1986. Platelet membrane glycoprotein IIb/IIIa: member of a family of arg-gly-asp-specific adhesion receptors. Science 231: 155962

Pytela, R., Pierschbacher, M. D., Ruoslahti, E. 1985a. Identification and isolation of a $140 \mathrm{kd}$ cell surface glycoprotein with properties expected of a fibronectin receptor. Cell 40: 191-98

Pytela, R., Pierschbacher, M. D., Ruoslahti, E. 1985b. A $125 / 115-\mathrm{kDa}$ cell surface receptor specific for vitronectin interacts with the arginine-glycine-aspartic acid adhesion sequence derived from fibronectin. Proc. Natl. Acad. Sci. USA 82: 5766-70

Quigley, J. P. 1979. Phorbol ester-induced morphological changes in transformed chick fibroblasts: evidence for direct catalytic involvement of plasminogen activator. Cell 17: 131-41

Rapraeger, A. C., Bernfield, M. 1983. Heparan sulfate proteoglycans from mouse mammary epithelial cells: a putative membrane proteoglycan associates quantitatively with lipid vesicles. J. Biol. Chem. 258: $3632-36$

Rinnerthaler, G., Geiger, B., Small, J. V. 1988. Contact formation during fibroblast locomotion: involvement of membrane ruffles and microtubules. J. Cell Biol. 106: 747-60

Risinger, M. A., Wilkins, J. A., Lin, S. 1987. Comparison of tensin and vinculin localizations in muscle and nonmuscle cells. $J$. Cell Biol. 105: 130a (Abstr.)

Rogalski, A. A. 1987. A plasma membrane integral sialoglycoprotein (Sgp130) molecularly distinguishes nonjunctional dense plaque sites of microfilament attachment. J. Cell Biol. 105: 819-31

Rogalski, A. A., Singer, S. J. 1985. An integral glycoprotein associated with the membrane attachment sites of actin microfilaments. J. Cell Biol. 101: 785-801

Rohrschneider, L. R. 1980. Adhesion plaques of Rous sarcoma virus-transformed cells contain the src gene product. Proc. Natl. Acad. Sci. USA 77: 3514-18

Rohrschneider, L. R., Najita, L. M. 1984. Detection of the v-abl gene product at cell-substratum contact sites in Abelson murine leukemia virus-transformed fibroblasts. J. Virol. 51: 547-52

Rohrschneider, L., Reynolds, S. 1985. Regulation of cellular morphology by the Rous sarcoma virus src gene: analysis of fusiform mutants. Mol. Cell. Biol. 5: 30973107

Rohrshneider, L., Rosok, M. J. 1983. Transformation parameters and $p^{60 \text { src }}$ localization in cells infected with partial trans- formation mutants of Rous sarcoma virus.

Mol. Cell. Biol. 3: 731-46

Rosenberg, S., Stracher, A., Burridge, K. 1981. Isolation and characterization of a calcium-sensitive $\alpha$-actinin-like protein from human platelet cytoskeleton. J. Biol. Chem. 256: 12986-91

Rosenfeld, G. C., Hou, D. C., Dingus, J., Meza, I., Bryan, J. 1985. Isolation and partial characterization of human platelet vinculin. J. Cell Biol. 100: 669--76

Rosok, M. J., Rohrschneider, L. R. 1983. Increased phosphorylation of vinculin on tyrosine does not occur during the release of stress fibers before mitosis in normal cells. Mol. Cell. Biol. 3: 475--79

Ruggeri, Z. M., Bader, R., DeMarco, L. 1982. Glanzmann thrombasthenia: deficient binding of von Willebrand factor to thrombin-stimulated platelets. Proc. Natl. Acad. Sci. USA 79: 6038-41

Ruoslahti, E., Pierschbacher, M. D. 1987. New perspectives in cell adhesion. Science 238: 491-97

Sanger, J. M., Mittal, B., Pochapin, M. B., Sanger, J. W. 1987. Stress fiber and cleavage furrow formation in living cells microinjected with fluorescently labeled $\alpha$-actinin. Cell Motil. Cytoskel. 7: 209-20

Sato, M., Schwarz, W. H., Pollard, T. D. 1987. Dependence of the mechanical properties of actin $/ \alpha$-actinin gels on deformation rate. Nature 325: $828-30$

Schlessinger, J., Geiger, B. 1981. Epidermal growth factor induces redistribution of actin and $\alpha$-actinin in human epidermal carcinoma cells. Exp. Cell Res. 134: 27379

Schliwa, M., Nakamura, T., Porter, K. R., Euteneuer, V. 1984. A tumor promoter induces rapid and coordinated reorganization of actin and vinculin in cultured cells. J. Cell Biol. 99: 1045--59

Schollmeyer, J. E., Furcht, L. T., Goll, D. E., Robson, R. M., Stromer, M. H. 1976. Localization of contractile proteins in smooth muscle cells and in normal and transformed fibroblasts. In Cell Motility, ed. R. Goldman, T. Pollard, J. Rosenbaum, pp. 361-88. New York: Cold Spring Harbor

Schroer, W., Wegner, A. 1985. Purification and characterization of a protein from chicken gizzard, which inhibits actin polymerization. Eur. J. Biochem. 153: 515-20

Sealock, R., Paschal, B., Beckerle, M., Burridge, K. 1986. Talin is a post-synaptic component of the rat neuromuscular junction. Exp. Cell Res. 163: 143-50

Sefton, B. M., Hunter, T., Ball, E. H., Singer, S. J. 1981. Vinculin: a cytoskeletal target of the transforming protein of Rous sarcoma virus. Cell 24: 165--74 
Senecal, J.-L., Fortin, S., Roussin, A., Joyal,

F. 1987. Anticytoskeletal autoantibody to microfilament anchorage sites recognizes novel focal contact proteins. J. Clin. Invest. 80: 778-85

Shattil, S. J., Hoxie, J. A., Cunningham, M., Brass, L. F. 1985. Changes in the platelet membrane glycoprotein IIb/IIIa complex during platelet activation. J. Biol. Chem. 260: 11 107-14

Shear, C. R., Bloch, R. J. 1985. Vinculin in subsarcolemmal densities in chicken skeletal muscle: localization and relationship to intracellular and extracellular structures. J. Cell Biol. 101: 240-56

Singer, I. I. 1979. The fibronexus: a transmembrane association of fibronectin-containing fibers and bundles of $5 \mathrm{~nm}$ microfilaments in hamster and human fibroblasts. Cell 16: 675-85

Singer, I. I., Kawka, D. W., Scott, S., Mumford, R. A., Lark, M. W. 1987a. The fibronectin cell attachment sequence arggly-asp-ser promotes focal contact formation during early fibroblast attachment and spreading. J. Cell Biol. 104: 573-84

Singer, I. I., Paradiso, P. R. 1981. A transmembrane relationship between fibronectin and vinculin (130kd protein): serum modulation in normal and transformed hamster fibroblasts. Cell 24: 481-92

Singer, I. I., Scott, S., Kawka, D. W., Hassel, J. R. 1987b. Extracellular matrix fibers containing fibronectin and basement membrane heparan sulfate proteoglycan coalign with focal contacts and microfilament bundles in stationary fibroblasts. Exp. Cell Res. 173: 558-71

Singer, I. I., Scott, S., Kawka, D. W., Kazazis, D. M., Gailit, J., et al. 1988. Cell surface distribution of fibronectin and vitronectin receptors depends on substrate composition and extracellular matrix accumulation. J. Cell Biol. 106: 2171-82

Small, J. V. 1981. Organization of actin in the leading edge of cultured fibroblasts: influence of osmium tetroxide and dehydration on the ultrastructure of actin meshworks. J. Cell Biol. 91: 695-705

Small, J. V. 1985. Geometry of actin-membrane attachments in the smooth muscle cell: the localizations of vinculin and $\alpha$ actinin. EMBO J. 4: 45-49

Small, J. V., Rinnerthaler, G. 1985. Cytostructural dynamics of contact formation during fibroblast locomotion in vitro. Expl. Biol. Med. 10: 54-68

Stickel, S. K., Wang, Y.-L. 1987. Alpha-actinin-containing aggregates in transformed cells are highly dynamic structures. $J$. Cell Biol. 104: 1521-26

Streeter, H. B., Rees, D. A. 1987. Fibroblast adhesion to RGDS shows novel features
105: $507-15$

Tamkun, J. W., DeSimone, D. W., Fonda, D., Patel, R. S., Buck, C., et al. 1986. Structure of integrin, a glycoprotein involved in the transmembrane linkage between fibronectin and actin. Cell 46: 27I-82

Tarone, G., Cirillo, D., Giancotti, F. G., Comoglio, P. M., Marchisio, P. C. 1985. Rous sarcoma virus-transformed fibroblasts adhere primarily at discrete protrusions of the ventral membrane called podosomes. Exp. Cell Res. 159: 14157

Tarone, G., Galetto, B., Prat, M., Comoglio, D. M. 1982. Cell surface molecules and fibronectin-mediated cell adhesion: effect of proteolytic digestion of membrane proteins. J. Cell Biol. 94: 179-86

Tidball, J. G. 1987. Alpha-actinin is absent from the terminal segments of myofibrils and from subsarcolemmal densities in frog skeletal muscle. Exp. Cell Res. 170: 46982

Tidball, J. G., O’Halloran, T., Burridge, K. 1986. Talin at myotendinous junctions. $J$. Cell Biol. 103: 1465-72

Tomasek, J. J., Hay, E. D., Fujiwara, K. 1982. Collagen modulates cell shape and cytoskeleton of embryonic corneal and fibroma fibroblasts: distribution of actin, $\alpha$-actinin, and myosin. Dev. Biol. 92: 10722

Trotter, J. A. 1981. The organization of actin in spreading macrophages. Exp. Cell Res. 132: $235-48$

Unkeless, J. C., Tobia, A., Ossowski, L., Quigley, J. P., Rifkin, D. B., et al. 1973. An enzymatic function associated with transformation of fibroblasts by oncogenic viruses: I. Chick embryo fibroblast cultures transformed by avian RNAtumor viruses. J. Exp. Med. 137: 85-111

Volberg, T., Sabanay, H., Geiger, B . 1986. Spatial and temporal relationships between vinculin and talin in the developing chicken gizzard smooth muscle. Differentiation 32: 34-43

Volk, T., Geiger, B. 1984. A 135 kD membrane protein of intracellular adherens junctions. EMBO J. 3: 2249-60

Wachsstock, D. H., Wilkins, J. A., Lin, S. 1987. Specific interaction of vinculin with $\alpha$-actinin. Biochem. Biophys. Res. Comm. 146: $554-60$

Wang, E., Yin, H. L., Krueger, J. G., Caliguiri, L. A., Tamm, I. 1984. Unphosphorylated gelsolin is localized in regions of cell-substratum contact or attachment in Rous sarcoma virus-transformed rat cells. J. Cell Biol. 98: 761-71

Wang, Y.-L. 1984. Reorganization of actin 
filament bundles in living fibroblasts. $J$. Cell Biol. 99: 1478-85

Werth, D. K., Niedel, J. E., Pastan, I. 1983. Vinculin, a cytoskeletal substrate for protein kinase. J. Biol. Chem. 258: 11423-26

Werth, D. K.,Pastan, I. 1984. Vinculin phosphorylation in response to calcium and phorbol esters in intact cells. J. Biol. Chem. 259: $5264-70$

Westermark, B., Porter, K. P. 1982. Hormonally induced changes in the cytoskeleton of human thyroid cells in culture. J. Cell Biol. 94: 42-50

Wilkins, J. A., Chen, K. Y., Lin, S. 1983. Detection of high molecular weight vinculin binding proteins in muscle and nonmuscle tissues with an electroblotoverlay technique. Biochem. Biophys. Res. Commun. 116: 1026-32

Wilkins, J. A., Lin, S. 1982. High-affinity interaction of vinculin with actin filaments in vitro. Cell 28: 83-90

Wilkins, J. A., Lin, S. 1986. A re-examination of the interaction of vinculin with actin. J. Cell Biol. 102: 1085-92

Wilkins, J. A., Risinger, M. A., Coffey, E., Lin, S. 1987. Purification of a vinculin binding protein from smooth muscle. $J$. Cell Biol. 104: 130a

Wilkins, J. A., Risinger, M. A., Lin, S. 1986. Studies on proteins that co-purify with smooth muscle vinculin: identification of immunologically related species in focal adhesions of nonmuscle and Z-lines of muscle cells. J. Cell Biol. 103: 1483-94

Willingham, M. C., Yamada, K. M., Yamada, S. S., Pouyssegur, J., Pastan, I. 1977. Microfilament bundles and cell shape are related to adhesiveness to substratum and are dissociable from growth

\section{5-80}

Woods, A., Couchman, J. R. 1988. Focal adhesions and cell-matrix interactions. Collagen Rel. Res. 8: 155-82

Woods, A., Couchman, J. R., Johansson, S., Hook, M. 1986. Adhesion and cytoskeletal organization of fibroblasts in response to fibronectin fragments. $E M B O$ J. 5: 665-70

Woods, A., Couchman, J. R., Hook, M. 1985. Heparan sulfate proteoglycans of rat embryo fibroblasts. J. Biol. Chem. 260: 10872-79

Woods, A., Hook, M., Kjellen, L., Smith, C. G., Rees, D. A. 1984. Relationship of heparan sulf ate proteoglycans to the cytoskeleton and extracellular matrix of cultured fibroblasts. J. Cell Biol. 99: 1743-53

Wright, S. D., Craigmyle, L. S., Silverstein, S. C. 1983. Fibronectin and serum amyloid $\mathrm{P}$ component stimulate $\mathrm{C} 3 \mathrm{~b}-$ and C3b-mediated phagocytosis in cultured human monocytes. J. Exp. Med. 158: 1338-43

Wright, S. D., Silverstein, S. C. 1982. Tumorpromoting phorbol esters stimulate C3b and $\mathrm{C}^{3} \mathrm{~b}^{\prime}$ receptor-mediated phagocytosis in cultured human monocytes. J. Exp. Med. 156: 1149-64

Yamada, K. M., Yamada, S. S., Pastan, I. 1976. Cell surface protein partially restores morphology, adhesiveness and contact inhibition of movement to transformed fibroblasts. Proc. Natl. Acad. Sci. USA 73: 1217-21

Zobel, C. R., Woods, A. 1983. Effect of calcium on the morphology of human platelets spread on glass substrates. Eur. $J$. Cell Biol. 30: 83-92 
W Volume 4, 1988

\section{CONTENTS}

Recent Studies of DNA in the Crystal, $H . R$. Drew, M. J. McCall, and C. R. Calladine

Environmentally Regulated Gene Expression for Membrane

ProteINS IN ESCHERICHIA COLI, Steven Forst and Masayori Inouye 21

Growth Cone Motility and Guidance, D. Bray and P. J. Hollenbeck

Hair Cells: Transduction, Tuning, and Transmission in the InNer Ear, W. M. Roberts, J. Howard, and A. J. Hudspeth

Cell-Associated Plasminogen Activation: Regulation and Physiological Functions, Olli Saksela and Daniel B. Rifkin

ENHANCERS: MeChaNisms of ACtion AND Cell SPECIFICITY, Michael L. Atchison

Mitochondrial Membrane Potential in Living Cells, Lan Bo Chen

Extracellular Matrix Assembly, John A. McDonald

Molecular Aspects of Fertilization in Flowering Plants, E. C. Cornish, M. A. Anderson, and A. E. Clarke

Structure ANd Biology of Proteoglycans, Erkki Ruoslahti

Regulation of Protein ExPORT From the ENDOPlasmic Reticulum, John K. Rose and Robert W. Doms

BIOGENESIS OF MITOCHONDRIA, Giuseppe Attardi and Gottfried Schatz

Functional Organization of THe NuClEar ENVElope, Larry Gerace and Brian Burke

Development of the Peripheral Nervous System from the Neural Crest, Nicole M. Le Douarin and Julian Smith

Regulation of Adenylyl Cyclase-Coupled $\beta$-Adrenergic ReCEPtors, Jeffrey L. Benovic, Michel Bouvier, Marc G. Caron, and Robert J. Lefkowitz

CONJUGation In SACCHAROMYCES CEREVISIAE, Fred Cross,

Leland H. Hartwell, Catherine Jackson, and James B. Konopka

From EgG to EpIthelium, Tom P. Flemming and Martin H. Johnson 
Focal AdHesions: Transmembrane Junctions BetweEn the EXTRACellular Matrix and THE Cytoskeleton, Keith Burridge, Karl Fath, Thomas Kelly, Glen Nuckolls, and Christopher Turner

Microtubule Dynamics aNd Kinetochore Function in Mitosis, T. J. Mitchison

New Collagens, New Concepts, Robert E. Burgeson

Assembly of Phospholipids into Cellular Membranes:

Biosynthesis, TRANSMEMBRaNe MOVEMENT, aNd INTRACELlular

Translocation, $W$. Robert Bishop and Robert M. Bell

Fatty Acylation of Proteins, Alan M. Schultz,

Louis E. Henderson, and Stephen Oroszlan

Chemotaxis in Eukaryotic Cells, Peter Devreotes and

Sally Zigmond

STRUCTURE AND UTILIZATION OF TUBULIN IsOTYPES, Kevin F. Sullivan INDEXES

Subject Index

Cumulative Index of Contributing Authors, Volumes 1-4

Cumulative Index of Chapter Titles, Volumes 1-4 